Research papers

\title{
Holocene sediment distribution on the inner continental shelf of northeastern South Carolina: Implications for the regional sediment budget and long-term shoreline response
}

\author{
Jane F. Denny a,*, William C. Schwab ${ }^{a}$, Wayne E. Baldwin ${ }^{a}$, Walter A. Barnhardt ${ }^{a}$, \\ Paul T. Gayes ${ }^{b}$, Robert A. Morton ${ }^{c}$, John C. Warner ${ }^{\mathrm{a}}$, Neal W. Driscoll ${ }^{\mathrm{d}}$, George Voulgaris ${ }^{\mathrm{e}}$ \\ ${ }^{a}$ U.S. Geological Survey, 384 Woods Hole Road, Woods Hole, MA, 02543, USA

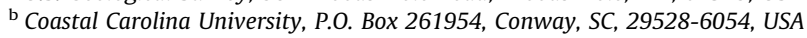 \\ ${ }^{\mathrm{c}}$ U.S. Geological Survey, 10100 Burnet Road, Building 130, Austin, TX 78758, USA \\ d Scripps Institution of Oceanography, 8602 La Jolla Shores Drive, La Jolla, CA, 92037, USA \\ e University of South Carolina, 701 Sumter Street, EWS 617, Columbia, SC, 29208, USA
}

\section{A R T I C L E I N F O}

\section{Article history:}

Received 11 April 2012

Received in revised form

29 January 2013

Accepted 15 February 2013

Available online 26 February 2013

\section{Keywords:}

Holocene sediment

coastal erosion

Long Bay

South Carolina

sediment budget

\begin{abstract}
A B S T R A C T
High-resolution geophysical and sediment sampling surveys were conducted offshore of the Grand Strand, South Carolina to define the shallow geologic framework of the inner shelf. Results are used to identify and map Holocene sediment deposits, infer sediment transport pathways, and discuss implications for the regional coastal sediment budget.

The thickest deposits of Holocene sediment observed on the inner shelf form shoal complexes composed of moderately sorted fine sand, which are primarily located offshore of modern tidal inlets. These shoal deposits contain $\sim 67 \mathrm{M} \mathrm{m}^{3}$ of sediment, approximately $96 \%$ of Holocene sediment stored on the inner shelf. Due to the lack of any significant modern fluvial input of sand to the region, the Holocene deposits are likely derived from reworking of relict Pleistocene and older inner-shelf deposits during the Holocene marine transgression. The Holocene sediments are concentrated in the southern part of the study area, due to a combination of ancestral drainage patterns, a regional shift in sediment supply from the northeast to the southwest in the late Pleistocene, and proximity to modern inlet systems. Where sediment is limited, only small, low relief ridges have formed and Pleistocene and older deposits are exposed on the seafloor. The low-relief ridges are likely the result of a thin, mobile veneer of sediment being transported across an irregular, erosional surface formed during the last transgression.

Sediment textural trends and seafloor morphology indicate a long-term net transport of sediment to the southwest. This is supported by oceanographic studies that suggest the long-term sediment transport direction is controlled by the frequency and intensity of storms that pass through the region, where low pressure systems yield net along-shore flow to the southwest and a weak onshore component.

Current sediment budget estimates for the Grand Strand yield a deficit for the region. Volume calculations of Holocene deposits on the inner shelf suggest that there is sufficient sediment to balance the sediment budget and provide a source of sediment to the shoreline. Although the processes controlling cross-shelf sediment transport are not fully understood, in sediment-limited environments such as the Grand Strand, erosion of the inner shelf likely contributes significant sediment to the beach system.
\end{abstract}

Published by Elsevier Ltd.

\footnotetext{
* Corresponding author. Tel.: +1 5084572311 .

E-mail addresses: jdenny@usgs.gov (J.F. Denny), bschwab@usgs.gov (W.C. Schwab), wbaldwin@usgs.gov (W.E. Baldwin), wbarnhardt@usgs.gov (W.A. Barnhardt), ptgayest@coastal.edu ( .T. Gayes), rmorton@usgs.gov (R.A. Morton), jcwarner@usgs.gov (J.C. Warner), ndriscoll@ucsd.edu (N.W. Driscoll), gvoulgaris@geol.sc.edu (G. Voulgaris).
}

\section{Introduction}

South Carolina's Grand Strand lies along an arcuate coastline extending from the North Carolina border south to Winyah Bay (Fig. 1). This section of coast is one of the most populated within South Carolina and includes heavily developed resort cities and coastal communities. Decadal-scale erosion rates for the Grand Strand are relatively low (Anders et al., 1990; Morton and Miller, 2005), 


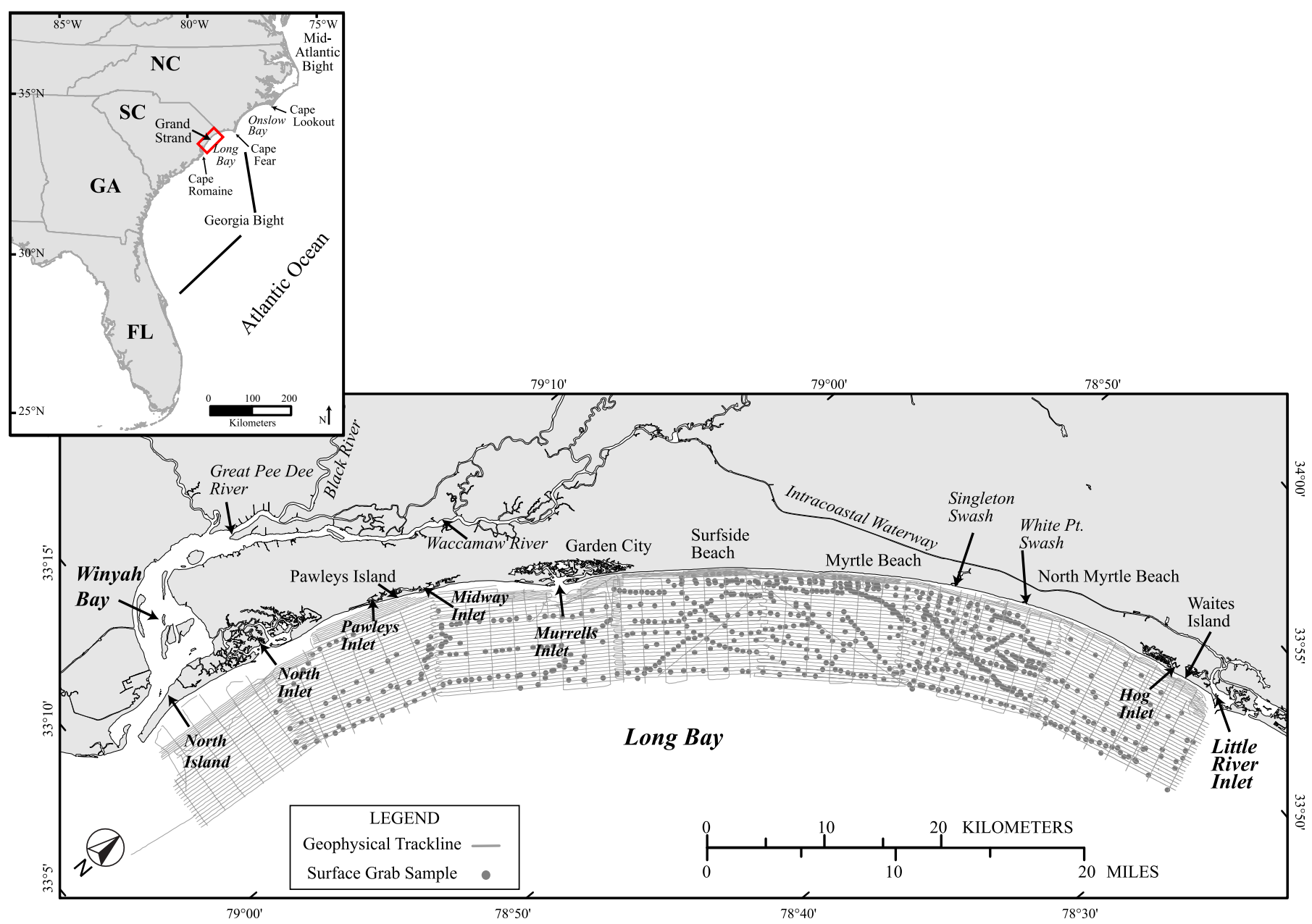

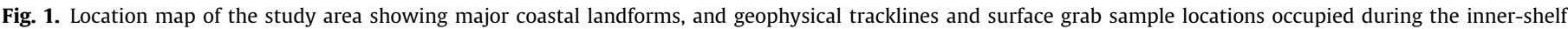
marine geophysical surveys. Insert map shows major water bodies, coastal landforms, and the study area outlined in black.

yet the economic impact of coastal erosion and storms has been costly to the region (Finkl and Pilkey, 1991; Gayes, 1991; Hayes and Michel, 2008; Stauble et al., 1991). Currently, beach nourishment is the most common method used in South Carolina to protect the shoreline from coastal erosion and severe storms. Nourishment is costly and controversial (Hayes and Michel, 2008) and requires a readily available source of sand. In order to identify and effectively manage the coastal resources needed to mitigate erosion and storm impacts along the Grand Strand, a better understanding of the factors influencing the evolution of the shoreline is needed.

The Grand Strand lies within Long Bay, an embayment bound by Cape Fear to the north and Cape Romaine to the south (Fig. 1). Presently, the region receives no direct input of fluvial sandy sediments, as no major rivers intersect the coast north of the Winyah Bay estuary (Hayes, 1994; Patchineelam et al., 1999). To the south, the Piedmont-draining Pee Dee River system joins several coastal plain rivers to form the Winyah Bay estuary. The Pee Dee River is the second largest source of fluvial sediment within the Georgia Bight (Hayes, 1994). However, the placement of dams along the Pee Dee River and trapping of fine-grained sediment within the bay and adjacent salt marshes have restricted sediment input into the littoral system of the Grand Strand (Hayes, 1994; Patchineelam et al., 1999). To the north, sediment from the Cape Fear River is predominantly deposited in the Cape Fear spit and shoal complexes (Denison, 1998; Patchineelam et al., 1999) and supplies minimal, if any, sand to the Long Bay coast (Hayes, 1994).
Because the Grand Strand littoral system is essentially a closed system without any external headland sources, beach sand must be derived from other sources, including erosion of the inner shelf, shoreface, and/or older shoreline deposits backing the modern beaches (Brown, 1977; Giles and Pilkey, 1965; Pilkey et al., 1981; Putney et al., 2004). The processes responsible for transporting sediment from the inner shelf to the shoreface are complex and poorly understood (e.g., Nittrouer and Wright, 1994; Warner et. al., 2012; Wright, 1987; Xu and Wright, 1998). However, nearshore studies have identified inner shelf sediment transport as an essential component of coastal sediment budgets (e.g., Batton, 2003; Conley and Beach, 2003; Hinton and Nicholls, 2007; Riggs et al., 1996, 1998; Schwab et al., 2000; Thieler et al., 1995, 2001; Wehmiller et al., 1995; Wright et al., 1991). Adding to the complexity of coastal sediment budgets and coastal change is the influence of a complex geologic framework of older stratigraphic units that occur beneath and seaward of the littoral zone (Belknap and Kraft, 1985; Evans et al., 1985; Harris et al., 2005; Locker et al., 2003; Miselis and McNinch, 2006; Riggs et al., 1995; Schwab et al., 1997, 2000; Thieler et al., 1995, 2001).

To better understand the factors controlling coastal erosion within the Grand Strand, the U.S. Geological Survey (USGS), in partnership with the South Carolina Sea Grant Consortium (SCSGC), conducted a series of geophysical and sampling surveys along the Long Bay inner shelf. The overall objectives are to provide an understanding of the shallow geologic framework and its role in coastal evolution, to identify and model the physical 
processes affecting coastal ocean circulation and sediment transport, and to identify sediment sources and transport pathways.

This paper builds upon the stratigraphic framework of the Long Bay inner shelf presented in (Baldwin et al., 2006) and describes the inner shelf in terms of seabed morphology and the distribution of Holocene sediment. Mapping results are used to identify inner shelf Holocene sediment deposits, infer sediment transport pathways, and discuss implications to the coastal sediment budget.

\section{Geologic setting}

\subsection{Coastal morphology}

The Grand Strand lies along $100-\mathrm{km}$ of coastline within the apex of Long Bay (Fig. 1). Long Bay represents a transition zone between the wave-dominated, microtidal coast of North Carolina and the tidally controlled, mesotidal coast of southern South Carolina and Georgia (Brown, 1977; Hayes, 1994; Hayes et al., 1993). The bay is characterized as a mixed- to wave-dominated energy environment, with a tidal range $<2 \mathrm{~m}$ and mean nearshore wave heights between 1.2 and $1.3 \mathrm{~m}$ (Hayes, 1994). Winds within Long Bay vary seasonally, but yearly averages show that winds generally align with the southwest/northeast orientation of the coast (Blanton et al., 1985; Brown, 1977). Northerly winds dominate in the fall and winter, and during the spring and summer south and southwest winds prevail (Blanton et al., 1985; Brown, 1977). Wind direction influences wave approach along this coastline. Predominant seas are from the northeast and southeast, which generates swell mostly from northeast and east (Anders et al., 1990). The northeast and east swell direction produces a dominant longshore current to the southwest within Long Bay (Brown, 1977).

Unlike the central and southern South Carolina coast, the Grand Strand has few barrier islands and tidal inlets and relatively narrow, poorly developed salt marshes (Brown, 1977; Hayes, 1994) (Fig. 1). Existing barrier islands and inlets are limited to the northern and southern extents of the study area. The central two-thirds of the Grand Strand is lined with sandy beaches that are welded to mainland Pleistocene barrier-island deposits (DuBar, 1971; Hayes, 1994; Putney et al., 2004). The mainland-attached shoreline has small, local drainage channels, or swashes, that drain the upland regions to the coast (Fig. 1) (Hayes, 1994). The mainland coast is considered to be relatively stable, as long-term shoreline erosion rates are less than $1 \mathrm{~m} / \mathrm{yr}$ (Anders et al., 1990; Morton and Miller, 2005). The areas of greatest shoreline change within the Grand Strand are around modern inlets (Fig. 2) (Anders et al., 1990; Morton and Miller, 2005).

\subsection{Geologic framework}

Repeated transgressive-regressive cycles during the PliocenePleistocene greatly modified the morphology of the Grand Strand and northern Long Bay. Piedmont and coastal plain rivers drained across the inner shelf during sea-level lowstands, deeply incising Cretaceous and Tertiary deposits (Colquhoun, 1972; Baldwin et al., 2006; Brown et al., 1980; Gayes et al., 1992; Wright et al., 1999). Sand supplied by rivers accumulated on the inner shelf seaward of the present shoreline. As sea level rose, inner-shelf and nearshore processes reworked these sand deposits. Across the lower coastal plain, thick Pliocene-Pleistocene barrier island complexes were deposited at various sea-level highstands. The paleo-barrier deposits decrease in age and elevation towards the present shoreline and record the landward extent of submergence through time (Colquhoun et al., 1991; Owens, 1989; Putney et al., 2004). The Myrtle Beach paleo-barrier complex backs the modern shoreline and was the last large Pleistocene barrier-island complex deposited across the entire Grand Strand coastline (DuBar and DuBar, 1980; McCartan et al., 1984; Owens, 1989).

On land, Holocene coastal deposits are distributed unevenly along the Grand Strand and form the present-day beaches. South of Murrells Inlet and north of Myrtle Beach, relatively thick and wide Holocene deposits form beaches, salt marshes, barrier islands, and spits (Putney et al., 2004). Along the mainland beaches of the Grand Strand, Holocene sand deposits are narrow and thin. Here, Pleistocene paleo-barrier deposits have eroded landward of the shoreline due to the lack of protective barriers (Putney et al., 2004). Storm-induced erosion commonly exposes semi-consolidated Tertiary-age deposits on the beach and upper shoreface in these areas (Gayes et al., 2003).

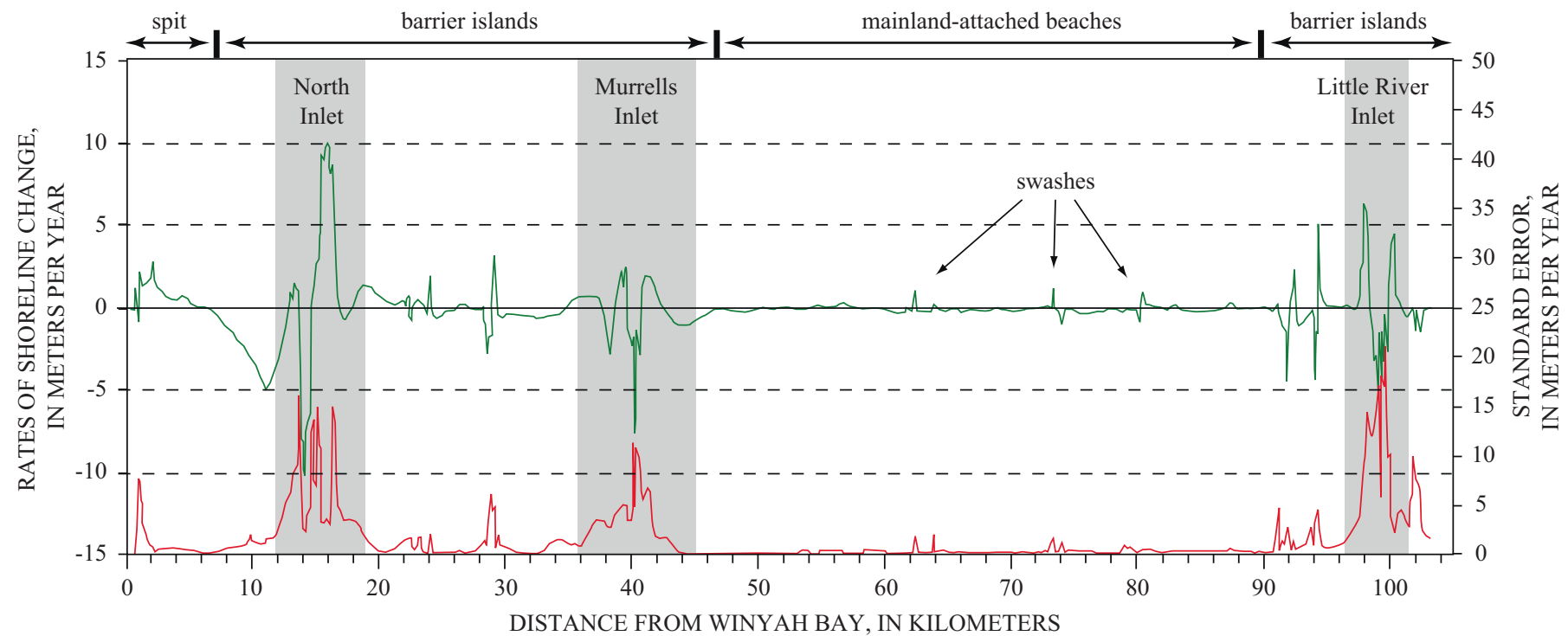

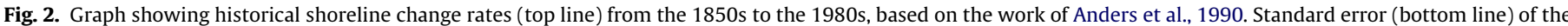

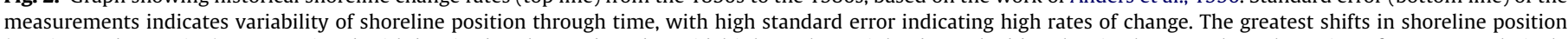

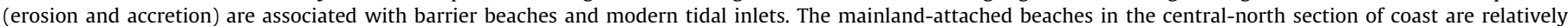
stable. 
Beach sediments along the Grand Strand are suggested to be primarily derived from erosion of the Pleistocene beach-ridge deposits backing the modern coast (Brown, 1977; Hayes, 1994) and possibly an offshore or shelf source (Giles and Pilkey, 1965). Beach sediments generally range from fine to medium sand (Brown, 1977; Slovinsky, 2001), with slightly finer-grained sediment in the north and gradually increasing in grain size to the south toward Surfside Beach/Garden City Beaches (Nelson, 1991).

\section{Methods}

The study area covers $\sim 800 \mathrm{~km}^{2}$ of the inner shelf from the shoreface to $\sim 9 \mathrm{~km}$ offshore (Fig. 1). Six geophysical surveys were conducted over a five year period (1999-2003): OctoberNovember 1999 aboard the R/V Atlantic Surveyor; March 2000 aboard the R/V Megan Miller, June 2002 aboard the R/V Atlantic Surveyor; and May 2001, 2002, and 2003 aboard the R/V Coastal II. Data from these cruises can be found in Baldwin et al. (2007), Dadisman et al. (2001a, 2001b), Hill et al. (2000a, 2000b), and Roberts et al. (2002).

Geophysical data were acquired using a chirp sidescan-sonar system (100-105 kHz), a chirp subbottom profiler $(2-7 \mathrm{kHz})$, a boomer subbottom profiler, $(300 \mathrm{~Hz}-3 \mathrm{kHz})$ and an interferometric sonar $(234 \mathrm{kHz})$ during offshore surveys aboard the R/V Atlantic Surveyor and R/V Megan Miller. Nearshore surveys aboard the R/V Coastal II used a dual-frequency (100/500 kHz) sidescan-sonar system, a chirp subbottom profiler $(500 \mathrm{~Hz}-12 \mathrm{kHz})$ and an interferometric sonar $(234 \mathrm{kHz})$. Positioning for the research vessels and geophysical and sampling instrumentation for all surveys was determined through use of Differential Global Positioning System (DGPS) navigation. A full description of data acquisition and processing procedures is presented in Baldwin et al. (2004, 2007) and Denny et al. (2007).

Surficial sediment samples (Fig. 1) were collected to provide groundtruth for acoustic backscatter and to characterize the surficial sediment distribution within the study area. Sample locations were selected based on backscatter variations observed in the sidescan-sonar mosaic (Fig. 3). A total of 722 grab samples were collected by Coastal Carolina University during three cruises aboard the NOAA vessels R/V Ferrel (2000-2001) and R/V Nancy Foster (2002). No samples were collected in the southern part of the study area between North Island and Winyah Bay. Grain-size analyses were conducted following the methodology of Poppe et al. (1985) and textural analysis results can be found in Denny et al. (2007).

Volume calculations of Holocene sediment thickness are based on high-resolution, chirp subbottom records. Only areas with sediment thickness of $1 \mathrm{~m}$ or greater were used in the calculations, as the vertical resolution of the seismic systems used within this study is on the order of $\sim 1 \mathrm{~m}$.

\section{Results}

\subsection{Seafloor morphology}

The inner shelf offshore of the Grand Strand is low relief and dips gently seaward (Fig. 4). Water depths range from $\sim 2 \mathrm{~m}$ at the shoreward edge to $14 \mathrm{~m}$ at the seaward edge of the survey area, roughly $9 \mathrm{~km}$ offshore. The seafloor gradient varies across the inner shelf with the steepest slopes averaging $7-8 \mathrm{~m} / \mathrm{km}$ in water depths less than $7 \mathrm{~m}$ and more gradual slopes of $0.5-1 \mathrm{~m} /$ $\mathrm{km}$ offshore, in water depths greater than $7 \mathrm{~m}$. The greatest bathymetric variability is found within shoal complexes that cross the survey area (Fig. 4).

The northernmost shoal complex abuts the shoreface of Waites Island and extends southwest along the coast from Little River Inlet to Hog inlet. The shoal is approximately $9 \mathrm{~km}$ in length and $2 \mathrm{~km}$ in width and extends from the shoreface to $\sim 9 \mathrm{~m}$ water depth (Fig. 4). Within the shoal complex, the shoreface has a smooth seaward-dipping slope.

A relatively large, shore-oblique shoal extends northwestsoutheast between the lower shoreface of northern Myrtle Beach and the seaward edge of the survey area in water depths ranging from $\sim 8$ to $10 \mathrm{~m}$ (Fig. 4). The shore-oblique shoal is approximately $2 \mathrm{~m}$ high, 5-6 km wide, $11 \mathrm{~km}$ long, and shows no discernible asymmetry.

Offshore of Murrells Inlet two well-developed shoals extend from the shoreface to the offshore extent of the survey area, ranging from $\sim 4$ to $12 \mathrm{~m}$ water depths (Fig. 4). These shoals are

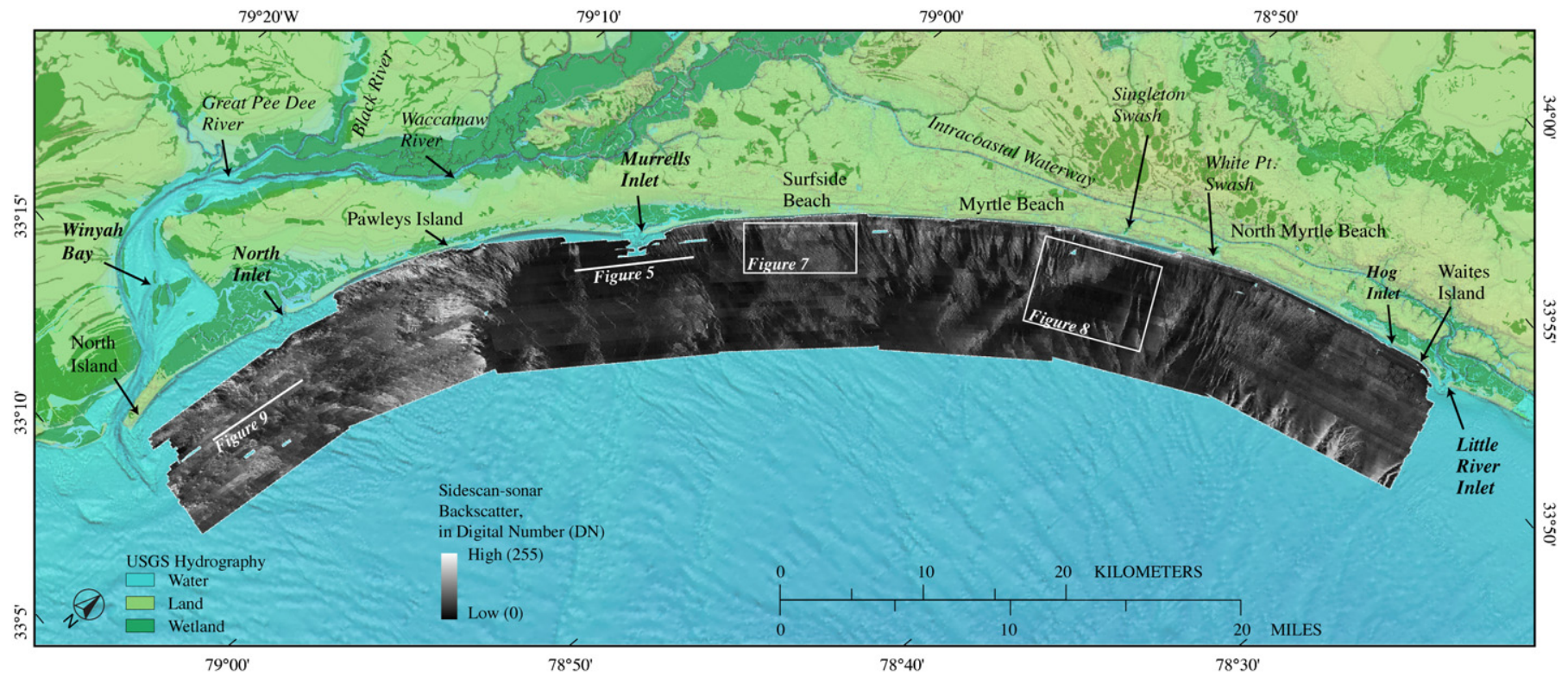

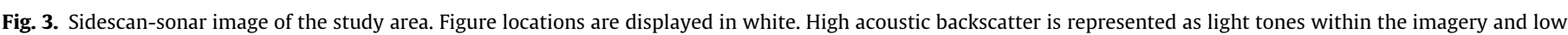

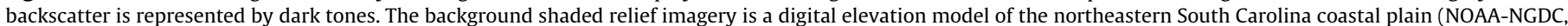
2001), overlain with USGS hydrography at a 1:24,000 scale. 


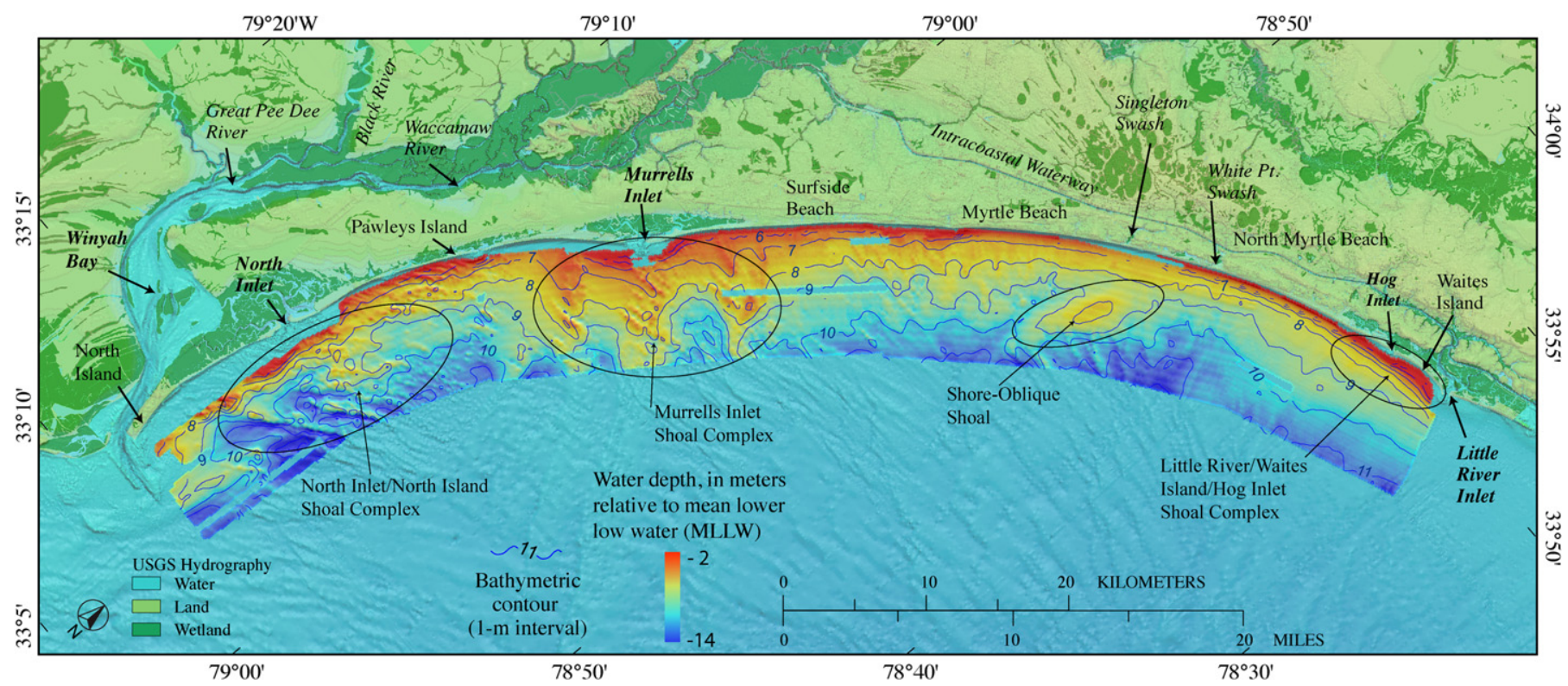

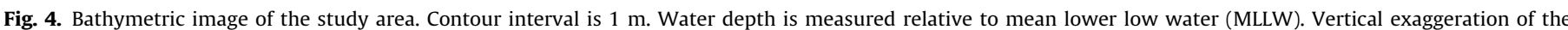

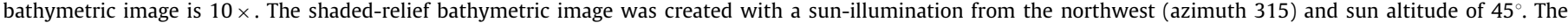

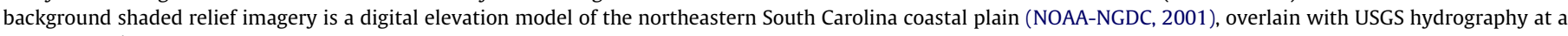
$1: 24,000$ scale.

1-2 m high, 4-5 km wide, $\sim 10 \mathrm{~km}$ long, and show slight but varied asymmetry. Superimposed on the shoals is a series of shore-oblique ridges oriented approximately $50^{\circ}$ from the shore that are $1 \mathrm{~m}$ in relief or less.

To the south, a large shoal complex centered at North Inlet extends from the nearshore bounds to the seaward limit of the survey area in water depths ranging from $\sim 4$ to $12 \mathrm{~m}$. The shoal complex as defined here includes a small inlet-associated shoal directly offshore of North Inlet and a series of shore-oblique ridges that cover the survey area off Pawleys and North Islands (Fig. 4). Ridges are oriented $\sim 35^{\circ}$ to the coast in the nearshore and $\sim 45-50^{\circ}$ to the coast offshore and average $\sim 2-3 \mathrm{~m}$ in relief, with locally higher relief up to $\sim 4 \mathrm{~m}$.

Relatively small, low relief ridges are present throughout the remainder of the survey area. The ridges are generally less than $1 \mathrm{~m}$ high and $\sim 1 \mathrm{~km}$ wide and range in length from $\sim 0.5-3 \mathrm{~km}$. They are commonly oblique to the shoreline, with acute angles opening to the northeast and have slight but varied asymmetry.

\subsection{Holocene sediment distribution}

Holocene sedimentary deposits on the Long Bay inner shelf overlie a regional unconformity that most likely represents multiple periods of transgression and regression across the inner shelf and lower coastal plain since the Pliocene-Pleistocene (Baldwin et al., 2004, 2006; Colquhoun et al., 1991; DuBar et al., 1974; Pilkey et al., 1981). This erosional surface is a major bounding unconformity separating truncated Cretaceous and Tertiary continental shelf deposits and Pleistocene paleochannel-fill deposits from younger Holocene sediments (Fig. 5). Within the seismic record, the Holocene deposits within Long Bay are acoustically transparent.

The thickest Holocene deposits on the Long Bay inner shelf were mapped in the southern and northern regions of the survey area (Fig. 6). Sediment cover within the central portion of the study area is thin to absent. Cretaceous and Tertiary continental shelf deposits and Pleistocene channel-fill deposits are exposed at the seafloor in these areas and form low relief hardgrounds (Fig. 7). Sediment recovered by grab samples shows that a thin, discontinuous veneer of sediment is present, but deposits are too thin $(<1 \mathrm{~m})$ to be resolved by the seismic systems used in this study.

At the northern boundary of the study area, Holocene deposits form the narrow shoal complex that abuts the shoreface off Little River Inlet (Fig. 6). Sediment thickness within the shoal complex ranges from 1 to $6 \mathrm{~m}$ and total sediment volume is $\sim 17 \mathrm{M} \mathrm{m}^{3}$ (Table 1).

Offshore of northern Myrtle Beach, Holocene sediments form a shore-oblique shoal (Fig. 8), predominately composed of mediumgrained quartz sand (Baldwin et al., 2004). Sediment is $\sim 3 \mathrm{~m}$ thick near the center of the shoal (Fig. 8), and total sediment volume is $\sim 5 \mathrm{M} \mathrm{m}^{3}$ (Table 1 ).

Holocene deposits in the south are concentrated around Murrells Inlet and North Inlet (Fig. 6). Holocene sediment within the shore-perpendicular shoals offshore of Murrells Inlet is approximately 1-4 m thick (Fig. 5) and total volume of the entire shoal complex is $\sim 23 \mathrm{M} \mathrm{m}^{3}$ (Table 1 ). Within the shoal complex offshore of North Inlet/North Island, sediment thickness ranges from $1 \mathrm{~m}$ to $4 \mathrm{~m}$ (Fig. 9) and total sediment volume is $\sim 22 \mathrm{M} \mathrm{m}^{3}$ (Table 1). Roughly, $67 \%\left(45 \mathrm{M} \mathrm{m}^{3}\right.$ ) of the sand stored in shoal complexes on the inner shelf lies in the southern third of the study area.

\subsection{Sediment texture}

Surface sediments within the Long Bay inner shelf are predominately siliciclastic sands (Denny et al., 2007). Grain sizes range from fine to coarse sand, with a mean grain size of medium sand (1.6 phi) (Fig. 10). Sediments show moderate to poor sorting (mean value 1.09) and are generally negatively skewed (mean value -0.29 ), with sediments within Little River shoal complex the most positively skewed (mean value 0.03 ) (Table 1 ).

Moderately sorted fine sands are concentrated within the shoal complexes with the exception of North Inlet shoal, which is poorly sorted, medium to coarse sand, strongly negatively skewed. Smaller pockets of moderately sorted, fine sand are also distributed along the crests of the small low-relief ridges offshore of Myrtle Beach and Surfside Beach. Moderate to poorly sorted medium sand covers much of the remainder of the shelf surface in the northern half of 


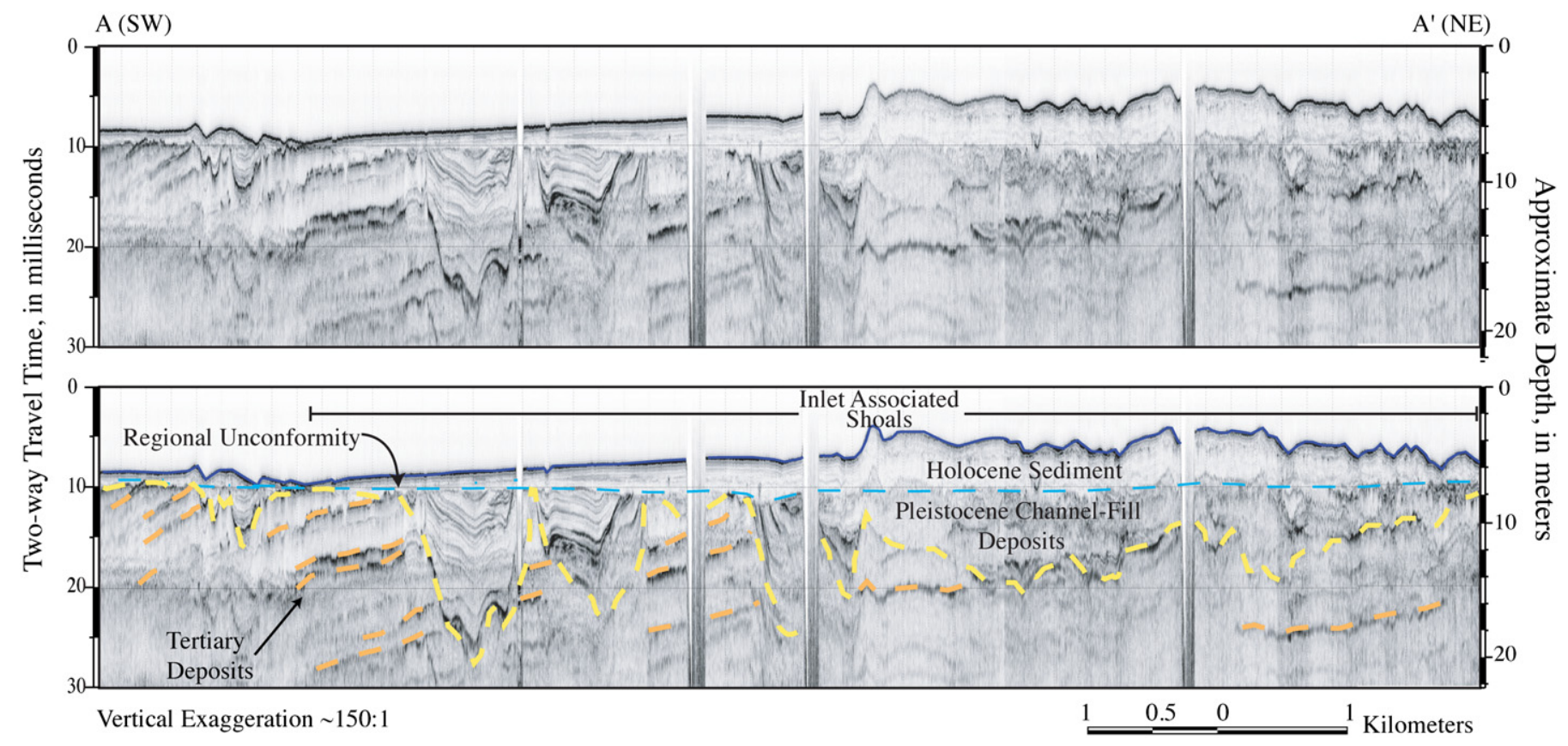

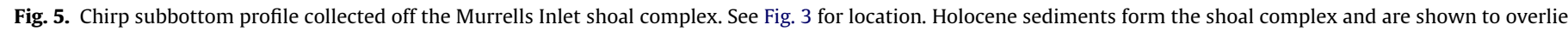

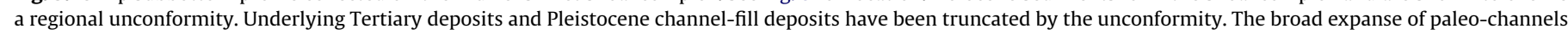
underlying the unconformity is likely associated with ancestral drainage of an inlet system at times of lower sea level (Baldwin et al., 2004).

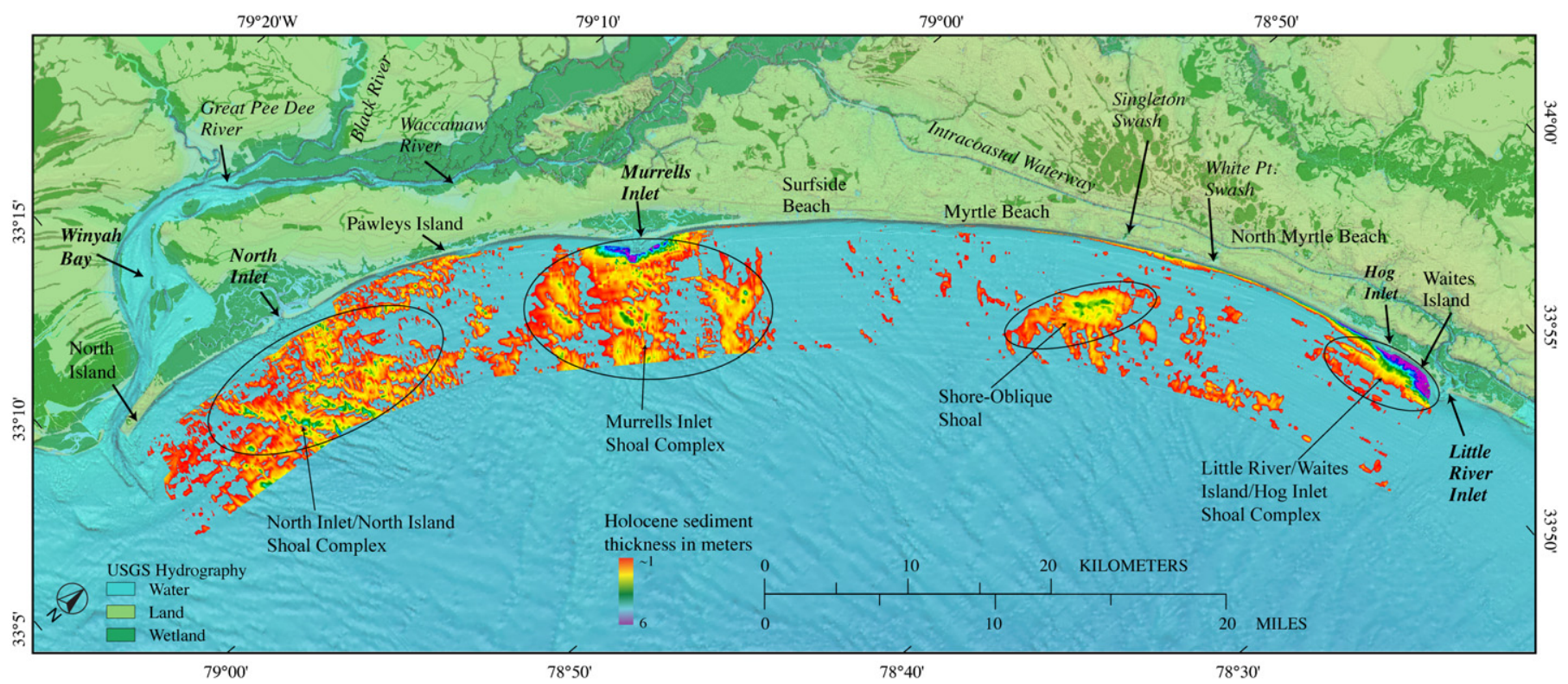

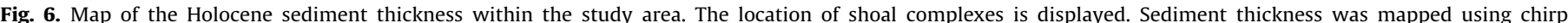

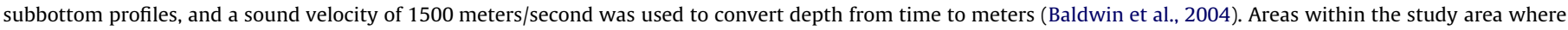

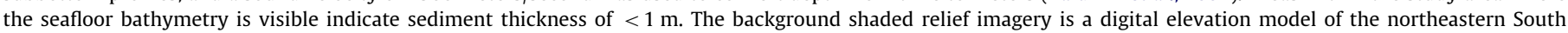
Carolina coastal plain (NOAA-NGDC, 2001), overlain with USGS hydrography at a 1:24,000 scale.

the study area. These sediments are generally negatively skewed. Much of the southern part of the study area away from shoals is poorly sorted coarse sand, also strongly negatively skewed. No sediment textural data are available south of North Inlet.

\section{Discussion}

\subsection{Inner-shelf holocene deposits}

The largest deposits of Holocene sediment preserved on the inner shelf form shoal complexes, primarily offshore of modern tidal inlets (Fig. 6). The Holocene sediments are generally moderately sorted fine sand, stand in relief against the gently, seaward dipping inner shelf, and are concentrated to the southwest. These deposits cover roughly one third of the survey area and contain $\sim 67 \mathrm{M} \mathrm{m}^{3}$ of sediment, approximately $96 \%$ of the sediment stored on the inner shelf (Table 1 ). With the exception of sediment exchange related to modern inlet processes, the Holocene sedimentary deposits are likely derived from reworking of relict fluvial and inner shelf deposits (Pleistocene channelfill and Cretaceous/Tertiary strata) during the most recent transgression and continue to be modified by oceanographic processes. 


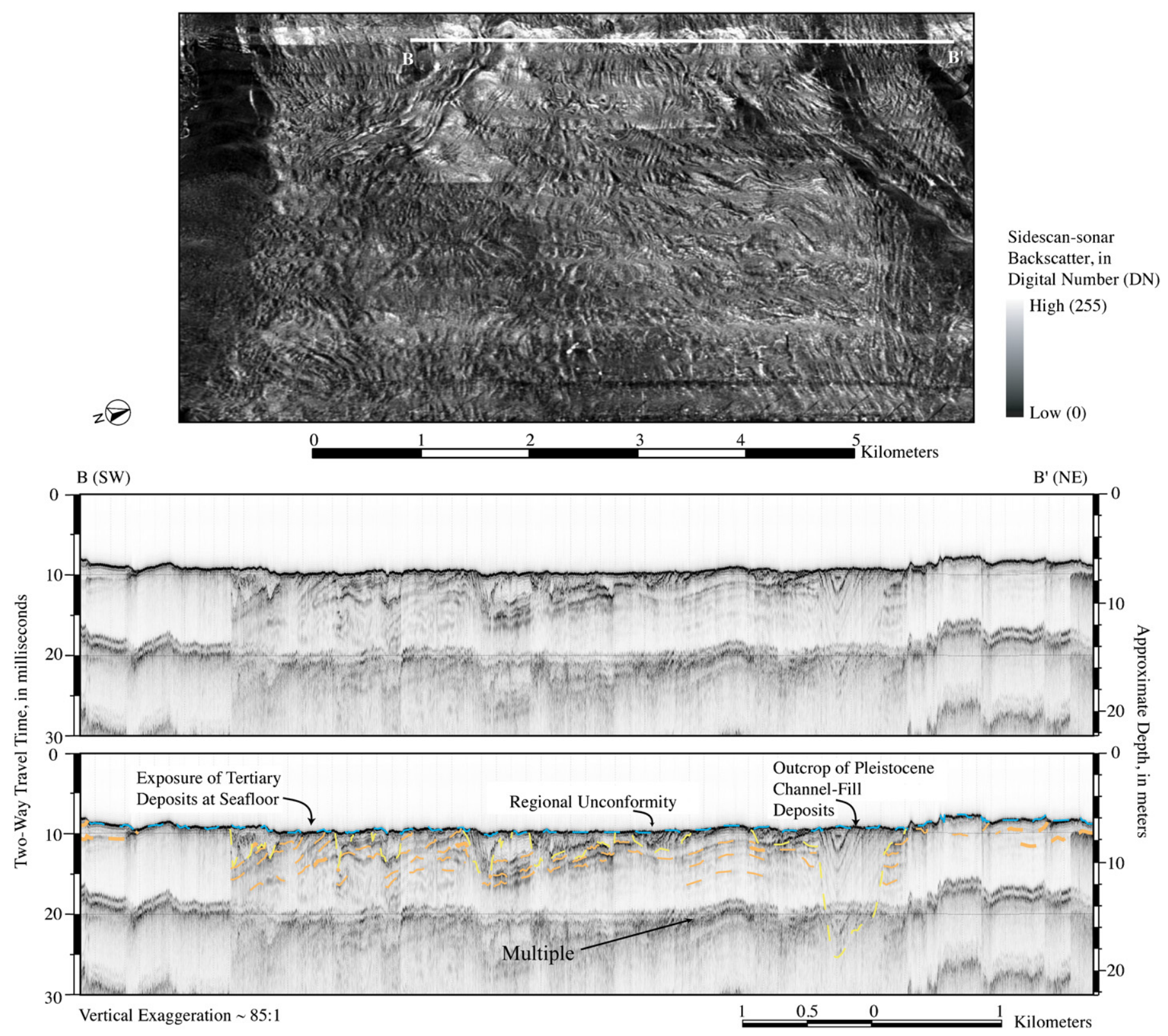

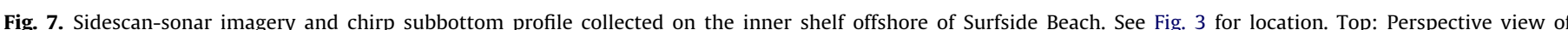

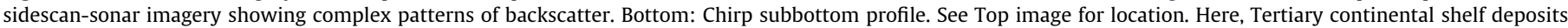

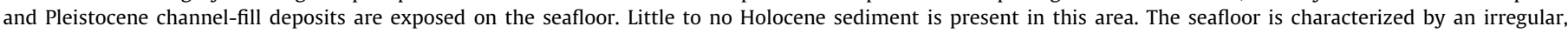

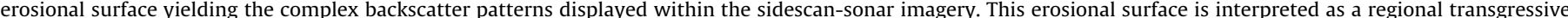

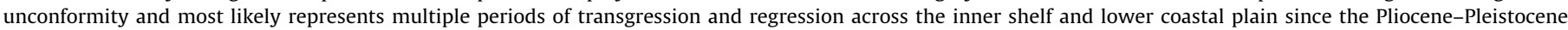
(Baldwin et al., 2004, 2006).

At the northern boundary of the study area, the Waites Island shoal complex abuts the shoreface and is associated with the modern Little River and Hog Inlets that bound the shoal to the north and south, respectively. Baldwin et al. (2004) mapped small channels lying above the regional unconformity in the nearshore off Waites Island. These features are interpreted as former drainage systems of tidal creeks, swashes, or small tidal inlets that formed when sea level was slightly lower than present. Based on evidence of earlier drainage in the area and its location off modern inlets, we interpret the Holocene deposit to mark the landward migration of the Waites Island transgressive barrier system during recent sea-level rise.

The shore-oblique shoal offshore of Myrtle Beach is anomalous, in that it is the only significant Holocene deposit on the inner shelf that is not associated with an active tidal inlet. The maximum age of the shoal is constrained by two radiocarbondated shells that returned ages of 4810-4520 cal. yr BP (Denny et al., 2007). We interpret the shoal to likely represent a reworked inlet deposit, possibly a remnant of a tidal delta or sand deposit constrained to the throat of an inlet, similar to the sand deposits of mixed-energy transitional inlets described by Hubbard et al. (1979). No active inlets presently lie inshore of the shoal deposit; however, the work of Baldwin et al. (2004) and Lennon et al. (1996) suggest that a tidal inlet may have existed at this location during the early Holocene. Small shallow channels mapped above the regional unconformity inshore of the shoal deposit indicate the presence of back-barrier creeks, swashes, or tidal channels (Baldwin et al., 2004). On land, a series of small lakes bound to the north and south by Whitepoint and Singleton swashes are interpreted to represent the remnants of a back-barrier lagoon 
Table 1

The major characteristics of the shoal complexes mapped on the inner shelf.

\begin{tabular}{|c|c|c|c|}
\hline Description of inner shelf region & Sediment characteristics ${ }^{a}$ & Area & Volume of holocene sediment \\
\hline Little River Shoal complex & $\begin{array}{l}\text { Fine sand }(2.2 \mathrm{phi}) \\
\text { Moderately sorted }(0.99) \\
\text { Fine skewed }(0.03)\end{array}$ & $20 \mathrm{~km}^{2}$ & $17 \mathrm{M} \mathrm{m}^{3}$ \\
\hline Shore-Oblique Shoal & $\begin{array}{l}\text { Fine sand }(2.2 \text { phi) } \\
\text { Moderately sorted }(0.78) \\
\text { Coarse skewed }(-0.23)\end{array}$ & $23 \mathrm{~km}^{2}$ & $5 \mathrm{M} \mathrm{m}^{3}$ \\
\hline Murrells Inlet Shoal complex & $\begin{array}{l}\text { Fine sand }(2.03 \text { phi }) \\
\text { Moderately sorted }(0.84) \\
\text { Coarse skewed }(-0.76)\end{array}$ & $156 \mathrm{~km}^{2}$ & $23 \mathrm{M} \mathrm{m}^{3}$ \\
\hline North Inlet/North Island Shoal complex & $\begin{array}{l}\text { Medium to coarse sand }(0.9) \\
\text { Poorly sorted }(1.2) \\
\text { Coarse skewed }(-0.38)\end{array}$ & $185 \mathrm{~km}^{2}$ & $22 \mathrm{M} \mathrm{m}^{3}$ \\
\hline Inner Shelf, excluding shoal complexes & $\begin{array}{l}\text { Medium to coarse sand (1.6 phi) } \\
\text { Moderately sorted }(1.09) \\
\text { Coarse skewed }(-0.29)\end{array}$ & $445 \mathrm{~km}^{2}$ & $2.3 \mathrm{M} \mathrm{m}^{3}$ \\
\hline Inner Shelf Totals & Fine to coarse siliciclastic sands & $830 \mathrm{~km}^{2}$ & $70 \mathrm{M} \mathrm{m}^{3}$ \\
\hline
\end{tabular}

\footnotetext{
${ }^{a}$ Mean values reported.
}
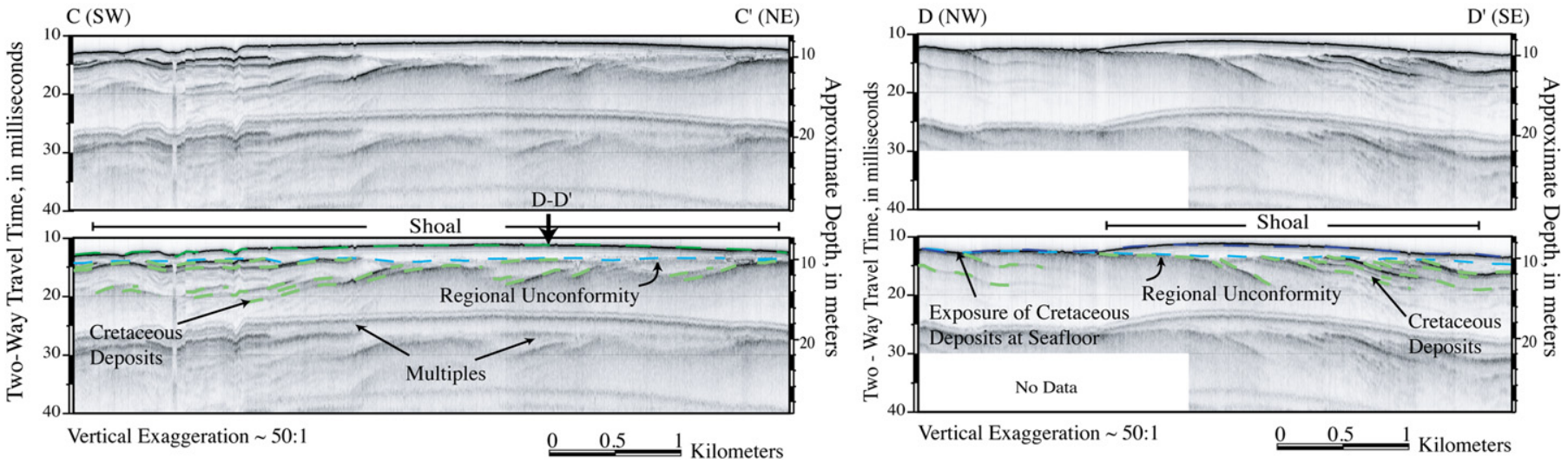

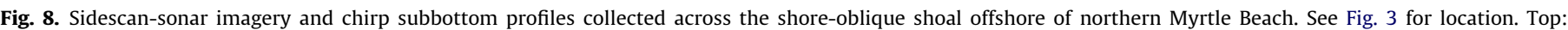

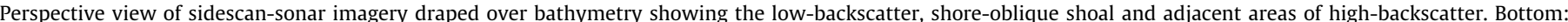

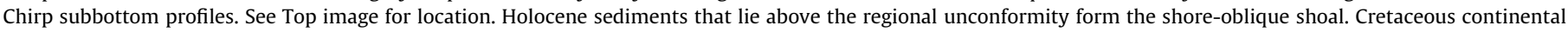

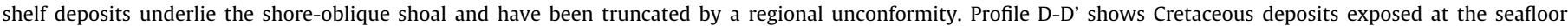
northwest of the shoal. These relict deposits yield complex patterns of high backscatter within the sidescan-sonar imagery. 


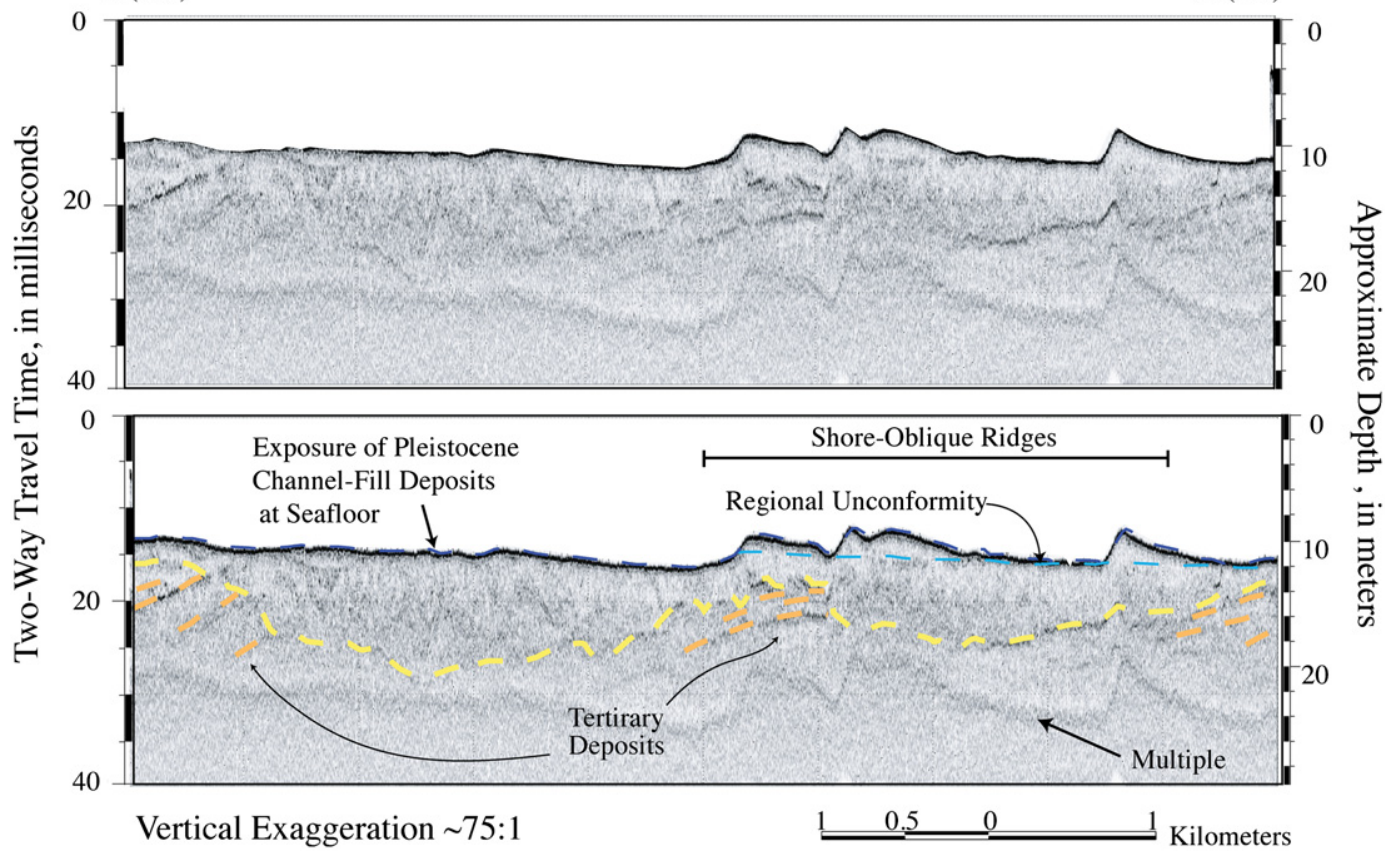

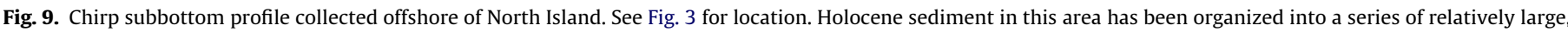

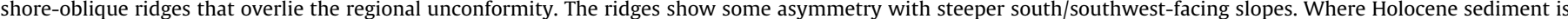

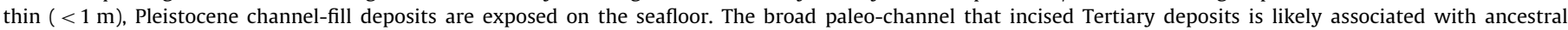
drainage of the Pee Dee River system (Baldwin et al., 2006).

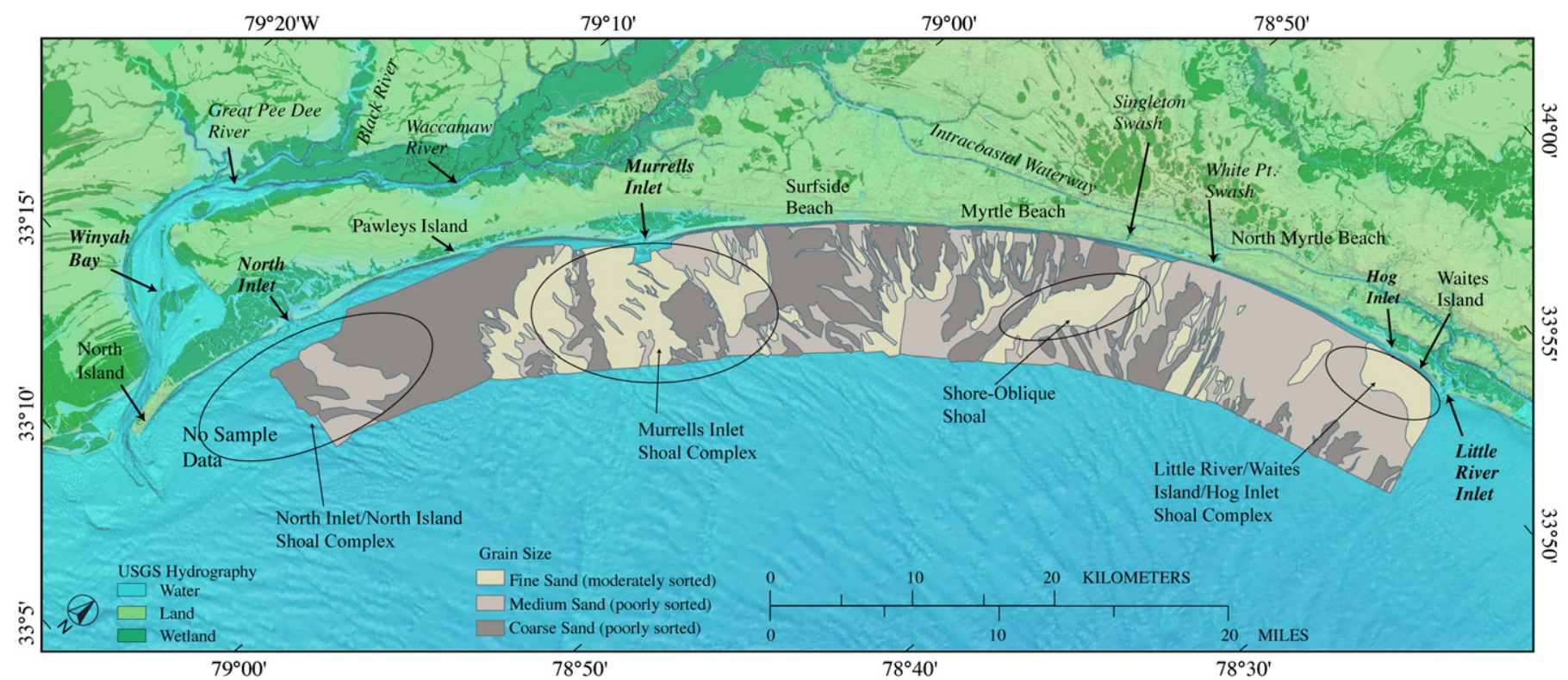

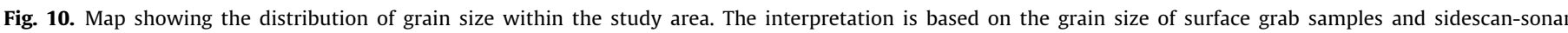

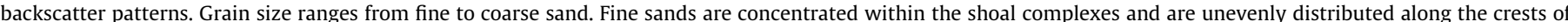

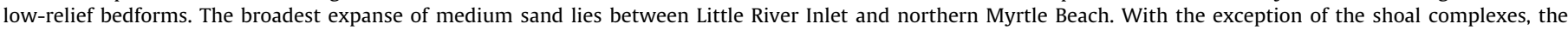

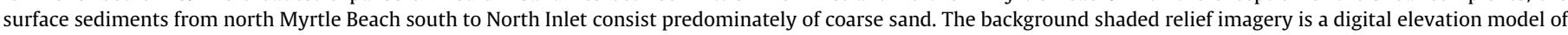
the northeastern South Carolina coastal plain (NOAA-NGDC, 2001), overlain with USGS hydrography at a 1:24,000 scale.

that was filled in as a transgressive barrier island welded to the mainland (Lennon et al., 1996). Elevated Pleistocene paleo-barrier deposits would have inhibited expansion of the lagoon further inland, and as the lagoon decreased in area, the tidal inlet eventually closed due to loss of tidal prism.

A series of small channels were also mapped in the nearshore off the Murrells Inlet shoal complex (Baldwin et al., 2004). These channels are interpreted as tidal creeks, swashes, or small tidal inlets that drained the upland regions at periods of lower sea level. Seismic records show that these channels are bound by two flat-lying erosional unconformities that merge in water depths of 6-8 m (Baldwin et al., 2004). The lower unconformity is interpreted as a tidal ravinement surface formed early in the transgression at the base of tidal channels or creeks. The upper unconformity likely represents the shoreface ravinement, marking surf zone erosion of marginal marine deposits during transgression. Following this interpretation, the shoal deposit represents the landward migration of the tidal inlet system as the shoreline 
transgressed, with the location of the inlet system constrained by the underlying framework. Drainage of the ancestral Pee Dee River system formed a topographic low across the lower coastal plain and inner shelf proximal to the modern Murrells Inlet (Baldwin et al., 2006; Gayes, 1992). The relict topography and more erodible fluvial deposits that fill this low are interpreted to have preferentially focused drainage and allowed maintenance of the inlet system in this location during transgression.

Based on stratigraphy from North Inlet and the Holocene sea-level curve of Brooks et al. (1989), Gardner and Porter (2001) postulated that at ca. $6.5 \mathrm{ka}$, sea level was $\sim 4 \mathrm{~m}$ below present, and the mouth of the Pee Dee River was located $\sim 5 \mathrm{~km}$ farther north and slightly offshore of its current position at the mouth of Winyah Bay. This interpretation matches well with a mapped channel described by Baldwin et al. (2004) that incised Tertiary deposits beneath North Island and across the study area, suggesting that the Pee Dee River system continued to occupy this area between the Last Glacial Maximum lowstand (ca. $\sim 20 \mathrm{ka}$ ) and the subsequent Holocene rise in sea level, until ca. $6.5 \mathrm{ka}$ (Baldwin et al., 2006). Thus, it is possible that some of the modern sediment forming the North Inlet/North Island shoal complex was derived from reworked early Holocene fluvial sediment deposited by the Pee Dee River.

The distribution of Holocene sediment on the inner shelf shows that more sediment lies to the southwest (Fig. 6). This is attributed to a combination of ancestral drainage patterns, a regional shift in sediment supply in the late Pleistocene, and sediment exchange related to modern inlet processes. Baldwin et al. (2006) developed a paleogeographic reconstruction of the ancestral Pee Dee River system within the lower coastal plain and inner shelf of Long Bay. They identified seven different locations where the Pee Dee River intersected the Grand Strand coastline from North Myrtle Beach to Winyah Bay between the late Pliocene and late Pleistocene. The slow southwestern migration of the Pee Dee River to its present location at Winyah Bay was primarily influenced by deposition of Pleistocene barrier island complexes on the coastal plain during sea-level highstands. The abundant supply of Blue Ridge, Piedmont and coastal plain sediments that supplied the large barrier-island complexes into the late Pleistocene was cut off as the Pee Dee migrated to its present position. Baldwin et al. (2006) suggest that a shift in regional sediment supply from central Long Bay to the south occurred within the late Pleistocene, evidenced by the reduced size and extent of Late Pleistocene and early Holocene shoreline deposits. Once the Pee Dee River occupied positions to the south, fluvial sediments were delivered too far to the south to be efficiently transported north by waves and currents to supply the coast with enough sediment to form thick barrier deposits. The reduced input of fluvial sediment to the region resulted in relatively thin and discontinuous Holocene deposits that form the modern beaches along the Grand Strand and influenced the present distribution of Holocene sediment on the inner shelf.

Where sediment is readily available on the inner shelf, waves, currents, and tides organize the deposits into a series of bedforms. Relatively large shore-oblique ridges have formed within the southern shoal complexes of Murrells Inlet and North Island/North Inlet (Fig. 9). The orientation of the ridges varies from $35^{\circ}$ to the coast in the nearshore to $50^{\circ}$ offshore. Where sediment is limited, only small, low relief ridges have formed on the inner shelf. These features are thought to be the result of a thin, mobile veneer of sediment being transported by modern littoral processes across an irregular, erosional surface that formed during the last transgression.

\subsection{Sediment transport pathways}

The general morphology of the inner shelf and local distribution and textural variation of sediment can be used to infer long- term net sediment transport directions within Long Bay. Despite the thin veneer of sediment over most of the north and central regions of the study area, present-day hydrodynamics have organized available sediment into a series of low-relief ridges. The ridges show some asymmetry with slightly steeper, southwest-facing slopes. Sediment distribution along the ridges displays a fairly consistent pattern. Moderately well sorted finegrained sand is generally concentrated along the crest and southwest-facing slope of the ridges and poorly sorted, coarsergrained sand is centered on the north-facing slopes and in the troughs between ridges (Fig. 11). We interpret this textural pattern to indicate a net transport of mobile material to the southwest. Currents transport fine-grained sand across the ridge crest, leaving coarser material in the trough between ridges and on the up-current northeast-facing slope. Similar processes have been described offshore of southern Long Island, New York by Schwab et al. (1997, 2000) where reworking of inner-shelf sediment deposits results in selective transport of finer-grained sediments, leaving behind a coarse-grained winnowed lag. Where sediment availability is greatest, such as offshore of North Island, well-developed ridges display clear asymmetry with steeper southwest-facing slopes (Fig. 9). The processes forming and maintaining these features is beyond the scope of this paper; however, these features are morphologically similar to shore-face attached ridges described in other nearshore areas (e.g. Calvete et al., 2001; Goff et al., 1999, Hayes and Nairn, 2004; McBride and Moslow, 1991; Snedden et al., 1999; Trowbridge, 1995; Van de Meene and Van Rijn, 2000; Vis-Star et al., 2007). Based on these studies, we interpret ridge orientation and asymmetry as a further indication of winnowing and net movement of the finer component to the south.

However, on a regional scale, textural variation of the inner shelf shows relatively more poorly sorted, coarser grained sediments in the southwest (Fig. 10). These sediments likely reflect the impact of fluvial drainage and sediment supply from the ancestral Pee Dee River system since the late Pleistocene. We suggest that although inner shelf deposits are being winnowed and finer sediment transported southward, the net sediment flux is not great enough to mask the original distribution of sediment, leaving a coarser signature to the southwest.

Warner et al. (2012) measured winds, currents, waves, and suspended sediment concentrations offshore of Myrtle Beach over a six-month period in 2003/2004. These data were analyzed to assess sediment transport processes on the inner shelf. Analyses of the data show that locally high winds correlate strongly with peaks in wave energy and although tidal-driven currents alone were not strong enough to mobilize sediment, oscillating currents associated with storm-wave-driven currents were able to suspend sediment. A combination of tidal and wind-driven surface currents and near-bed circulation during wave events was found to influence the direction and magnitude of sediment transport within Long Bay (Warner et al., 2012). Additionally, modeling results show that different storm patterns that pass through the region influence the magnitude and direction of sediment transport (Warner et al., 2012). Cold fronts and warm fronts were found to generally drive sediment toward the northeast. During passage of these fronts, wind initially blows out of the southwest and shifts to the northeast (cold front), or blows out of the northeast and shifts to the southwest (warm front). The winds from the southwest have a stronger influence on the direction of sediment movement due to the larger fetch and thus the generation of larger waves. Low-pressure systems (e.g. nor'easters), however, were found to drive sediment to the southwest in a constant, uni-directional pattern. Winds blow primarily from a northerly direction and strong wind-generated currents and waves are directed towards the south. 

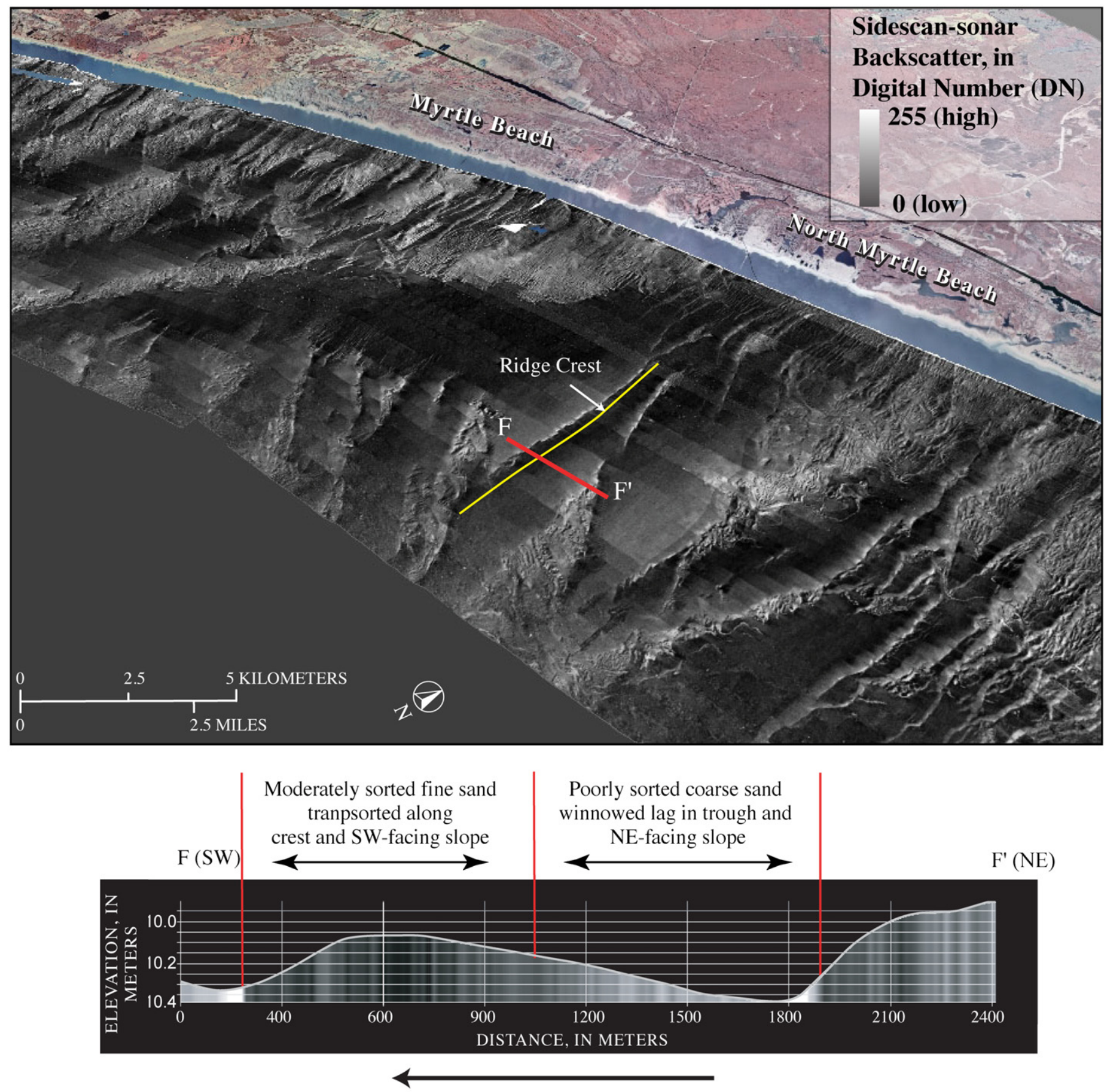

Inferred direction of sediment transport

Fig. 11. Top: Perspective view of the inner shelf offshore of Myrtle Beach shows sidescan-sonar imagery draped over bathymetry. Vertical exaggeration is $200 \times$. Bottom: Shore-parallel bathymetric profile across a characteristic low-relief ridge. See Top image for location. Backscatter and grain size variations are shown in relation to ridge morphology. Fine sand is concentrated on the ridge crest and steeper, south-facing slope. Medium to coarse-grained sediment is focused within the trough between ridges and along the north-facing slope. Currents transport fine sand and deposit sediment on the ridge crests and south-facing slopes, winnowing finer sediment from the trough and north-facing slopes, leaving a coarse lag. The geomorphic and textural variations suggest a long-term southwest transport of sediment within the study area. (Figure modified from Barnhardt, 2009).

During the observation period described by Warner et al. (2012), net along-shore sediment transport was towards the southwest, with a weaker cross-shore component directed onshore. These observations add support to our interpretation of the offshore mapping data, where qualitative analysis of innershelf morphology, sediment distribution and sediment textural trends indicates long-term net movement of sediment alongshore to the southwest. The weak onshore-directed flow component observed by Warner et al. (2012) indicates that the mobile sediment mapped on the inner-shelf can indeed be transported onshore during the dominant weather storm events affecting the study area. This process driving cross-shore sediment transport has broad implications for the development of regional coastal sediment budgets by identifying the inner shelf as a viable sand source.

The oceanographic observations and geologic interpretations of the Long Bay inner shelf apply to different temporal scales, 
however the results of both studies support net transport of sediment to the southwest, and the work of Warner et al. (2012) further suggests that low-pressure systems are the primary events driving sediment flux within the study area.

\subsection{Regional sediment budget}

Gayes et al. (2003) developed a regional "conceptual sediment budget" for the Grand Strand to provide a qualitative model of the long-term processes affecting shoreline behavior. Sources, sinks, and net sediment transport pathways were defined based on beach profiles, historical shoreline data and long-term erosion rates (Anders et al., 1990; Morton and Miller, 2005), U.S. Army Corps of Engineers dredging records, and geophysical data collected onshore (Putney et al., 2004) and offshore (Baldwin et al., 2004) (Table 2). This conceptual sediment budget assumes that the total volume of sediment within the coastal system remains constant (losses are balanced by gains), and that the system receives no additional sediment from fluvial sources or adjacent coasts to the north and south.

The total sediment source of $\sim 104,000 \mathrm{~m}^{3} / \mathrm{yr}$ eroded from the shoreface and $\sim 495,000 \mathrm{~m}^{3} / \mathrm{yr}$ accounted for from sink estimates leaves a deficit of $\sim 391,000 \mathrm{~m}^{3} / \mathrm{yr}$ in the conceptual sediment budget (Table 2). Engineering studies resolve such deficits by focusing on potential sand sources in the shoreface and subaerial segments of the coastal system (e.g. Kana, 1995). These approaches assume a 'depth of closure', a water depth considered the seaward limit of significant net sediment transport between the nearshore and the offshore (Bruun, 1962; Douglas, 1995; Hallermeier, 1981a, 1981b; Birkemeier, 1985; Heilman et al., 2006; Lee and Birkemeier, 1993; Nicholls et al., 1998). Depth of closure for the Grand Strand has been defined as $\sim 5-8 \mathrm{~m}$ (Park et al., 2009; USACE, 2007). Offshore mapping results (Putney et al., 2004 and this paper: Fig. 6) indicate no adequate source of sediment exists within these limits to balance the coastal sediment budget of Gayes et al. (2003), leading these authors, Ojeda et al. (2004) and Park et al. (2009) to suggest that the deficit in the sediment budget can be addressed by the input of sediment from the inner shelf to the shoreface. The concept of cross-shelf sediment flux is supported by other studies that point to erosion of the inner shelf as a significant source of sediment to the shoreface (e.g., Demarest and Leatherman, 1985; Hine and Snyder, 1985; Milliman et al., 1972; Morton et al., 1995; Pierce, 1969; Pilkey and Field, 1972; Pilkey et al., 1981; Pilkey et al., 1993; Riggs et al., 1995, 1996, 1998; Schwab et al., 1997, 2000, 2013; Snedden et al., 1988; Thieler et al., 1995, 2001; Wehmiller et al., 1995). These and other geologic studies discount the concept of depth of closure as an adequate measure of decadal- to centennial-scale shoreline evolution, despite its standard use in engineering applications.

Based on volume calculations of the Holocene sediment in this study, we determined that the available volume of sediment on the inner shelf is $\sim 70 \mathrm{M} \mathrm{m}^{3}$ (Table 1 ). These estimates suggest that there is sufficient volume of sediment to account for the $\sim 391,000 \mathrm{~m}^{3} / \mathrm{yr}$ deficit within the conceptual sediment budget proposed by Gayes et al. (2003), but the distribution of sediment is not uniform on the shelf. The largest inner shelf Holocene deposits lie offshore of the most dynamic areas of the coast. Longterm erosion rates (Anders et al., 1990; Morton and Miller, 2005) show that the greatest amount of change in shoreline position over the period from the 1850s to the 1980s has occurred around inlets and some of the larger swashes along the Grand Strand (Fig. 2). Rates of change of up to $10 \mathrm{~m} / \mathrm{yr}$ have been documented for segments of the barrier-island shoreline adjacent to North, Murrells, and Little River Inlets (Anders et al., 1990; Morton and Miller, 2005). These shoreline segments are fronted by relatively large accumulations of Holocene sediment on the inner shelf and are backed by Holocene salt marshes. In comparison, the mainland-attached beaches along the central portion of the Grand Strand, which have a smaller offshore sand source, have remained relatively stable, with rates of retreat generally $<0.5 \mathrm{~m} / \mathrm{yr}$ (Figs. 2 and 6) (Anders et al., 1990; Gayes et al., 2001). The relatively stable central beaches are fronted by erosion-resistant exposures of older Cretaceous, Tertiary, and Pleistocene channelfill deposits (Baldwin et al., 2004), with only a thin veneer of modern sediment present on the inner shelf, and backed by Pleistocene shoreline deposits. We speculate that the relative stability of the central mainland-attached beaches is due to the erosion-resistant nature of the shoreface; however, minor erosion must be occurring to maintain the thin sediment cover that forms the modern beach. If we are to believe that there is a sediment deficit, the most likely place for this exchange is along the barrierisland segments of coast where we have mapped the largest sediment bodies (likely source) and shoreline change analysis shows that the shoreline is more dynamic in behavior.

\section{Conclusions}

The largest deposits of Holocene sediment preserved on the Long Bay inner shelf form shoal complexes offshore of modern tidal inlets and within a shore-oblique shoal deposit offshore of Myrtle Beach. These deposits cover roughly one third of the survey area and contain $\sim 67 \mathrm{M} \mathrm{m}^{3}$ of sediment, approximately $96 \%$ of the sediment stored on the inner shelf. Due to a general lack of modern fluvial sand flux into the region, the inner-shelf

Table 2

Conceptual sediment budget for the Grand Strand based on Gayes et al., 2003.

\begin{tabular}{|c|c|c|}
\hline Sediment sinks (losses) & Volume ( $\mathbf{m}^{3} /$ year) & Basis of estimate \\
\hline Winyah bay & 284,000 & 1994-2002 maintenance-dredging records \\
\hline North Island spit & 79,000 & Historic spit growth, indicating sediment transport out of the system to the south \\
\hline North inlet & $?$ & \\
\hline Murrells inlet & 75,000 & 1974-1978 dredging records \\
\hline Hog inlet & $?$ & \\
\hline Little river inlet & 57,000 & 1982-1995 dredging records; limited net sediment out of the system to the north \\
\hline Total sinks & 495,000 & \\
\hline \multicolumn{3}{|l|}{ Sediment sources (gains) } \\
\hline Rivers & Small & Patchineelam et al. (1999) \\
\hline Beach and shoreface erosion & 104,000 & Gayes et al. (2001, 2003) \\
\hline Inner shelf erosion & $?$ & \\
\hline Total sources & 104,000 & \\
\hline Deficit & 391,000 & Sinks minus sources \\
\hline
\end{tabular}


Holocene deposits are likely derived from antecedent deposits reworked during the Holocene transgression. Thicker Holocene sediment deposits in the southwestern region of the study area are due to a combination of ancestral drainage patterns, a regional shift in sediment supply from northeast to southwest in the late Pleistocene, and sediment exchange related to modern inlet processes.

Mapping results (sediment distribution, bedform morphology, and sediment textural variation) along the inner shelf indicate a long-term southwesterly transport of sediment within Long Bay. Oceanographic studies suggest that the frequency and intensity of different storm types that pass through the region control the long-term sediment transport direction, with low pressure systems (e.g. nor'easter) dominating a net southwesterly along-shore transport direction with a weak onshore directed cross-shore component.

The long-term response of the shoreline appears to be closely tied to sediment availability and the geologic framework of the inner shelf. The stable regions of the shoreline lie along mainland beaches abutting Pleistocene shoreline deposits and fronted by erosion-resistant relict deposits exposed on the seafloor. Little to no Holocene sediment cover is present in these areas. The greatest rates of change in shoreline position occur around inlets and swashes where ample Holocene sediment is stored in the shoreface and inner shelf.

Due to a lack of any other significant source of sediment to the Grand Strand, erosion of the shoreface and inner shelf is the only available source of sand to balance the sediment budget. Although the processes controlling cross-shelf transport are complex and remain poorly understood, continued improvement of sediment transport modeling within Long Bay and other coastal systems (sand rich and sand starved) will aid in refining coastal sediment budgets, yielding a better understanding of decadal- to centennial-scale evolution of coastal systems, and predicting future coastal response to storms and long-term response to continued rise in sea level.

\section{Acknowledgments}

We thank Tom O'Brien, William Danforth, Dave Nichols, Shawn Dadisman, Jenna Hill, Charles Worley, Barry Irwin, Paul Byham, Richard Goldberg, Elizabeth Johnston, Neil Gielstra, German Ojeda, and Jamie Phillips for their support during field operations. Additionally, we thank the crews of the R/V Atlantic Surveyor, R/V Megan Miller, and the R/V Coastal II for their support during field efforts. We thank Dr. David Twichell and Dr. Daniel Brothers for their thorough reviews of this document.

\section{References}

Anders, F.L., Reed, D.W., Meisburger, E.P., 1990. Shoreline movements-Report 2, Tybee Island, Georgia, to Cape Fear, North Carolina, 1851-1983. USACE Technical Report, CERC-83-1, pp.1-164.

Baldwin, W.E., Morton, R.A., Denny, J.F., Dadisman, S.V., Schwab, W.C., Gayes, P.T., Driscoll, N.W., 2004. Maps showing the stratigraphic framework of South Carolina's Long Bay from Little River to Winyah Bay. U.S. Geological Survey Open-File Report, 2004-1013〈http://pubs.usgs.gov/of/2005/1346/〉.

Baldwin, W.E., Morton, R.A., Putney, T.R., Harris, M.S., Gayes, P.T., Driscoll, N.W., Denny, J.F., Schwab, W.C., 2006. Migration of the Pee Dee River system inferred from ancestral paleochannels underlying the South Carolina Grand Strand and Long Bay inner shelf. Geologic Society of America Bulletin 118, 533-549.

Baldwin, W.E., Denny, J.F., Schwab, W.C., Gayes, P.T., Morton, R.A., Driscoll, N.W., 2007. Geologic framework studies of South Carolina's Long Bay from Little River Inlet to Winyah Bay, 1999-2003; geospatial data release. U.S. Geological Survey Open-File Report 2005-1346 〈http://pubs.usgs.gov/of/2005/1346/〉.

Barnhardt, W.A., 2009. Coastal change along the shore of Northeastern South Carolina-The South Carolina Coastal Erosion Study. U.S. Geological Survey Circular 1339, 1-77.
Batton, B.K., 2003. Morphologic typologies and sediment budget for the ocean shoreline of Long Island. Stony Brook, Ph.D. Dissertation, New York: State University of New York at Stony Brook, Marine Sciences Research Center, p.116.

Belknap, D.F., Kraft, J.C., 1985. Influence of antecedent geology on stratigraphic preservation potential and evolution of Delaware's barrier systems. Marine Geology 63, 235-262.

Birkemeier, W.A., 1985. Field data on seaward limit of profile change. Journal of Waterway, Port, Coastal, and Ocean Engineering 111, 598-602.

Blanton, J.O., Schwing, F.B., Weber, A.H., Pietrafesa, L.J., Hayes, D.W., 1985. Wind stress climatology in the South Atlantic Bight. In: Atkinson, L.P., Menzel, E.W. Bush, K.A. (Eds.), Oceanography of the Southeastern U.S. Continental Shelf American Geophysical Union, Washington, D.C., pp. 10-22.

Brooks, M.M., Stone, P.A., Colquhoun, D.J., Brown, J.G., 1989. Sea level change, estuarine development and temporal variability in Woodland period subsistence-settlement patterning on the Lower Coastal Plain of South Carolina. In: Goodyear, A.C., Hanson, G.T., (Eds.), Studies in South Carolina archaeology in honor of Robert L. Stephenson. Anthropological Studies \#9, South Carolina Institute of Archaeology and Anthropology, University of South Carolina, Columbia South Carolina, pp. 91-100.

Brown, P.J., 1977. Variations of South Carolina coastal morphology. Southeastern Geology 18 (4), 249-264.

Brown, P.J., Ehrlich, R., Colquhoun, D.J., 1980. Origin of patterns of quartz sand types on the southeastern United States continental shelf and implications on contemporary shelf sedimentation-Fourier grain shape analysis. Journal of Sedimentary Petrology 50, 1095-1100.

Bruun, P., 1962. Sea-level rise as a cause of shore erosion. Journal Waterways and Harbors. Division 88, 117-132.

Calvete, D., Falqués, A., de Swart, H.E., Walgreen, M., 2001. Modelling the formation of shoreface-connected sand ridges on storm-dominated inner shelves. Journal of Fluid Mechanics 441, 169-193.

Colquhoun, D.J., Johnson, G.H., Peebles, P.C., Huddlestun, P.F., Scott, T., 1991 Quaternary geology of the Atlantic Coastal Plain. In: Morrison, R.B. (Ed.) Quaternary Nonglacial Geology: Conterminous U.S., The Geology of North America, v. K-2. Geological Society of America, Boulder, Colorado, pp. 629-650.

Conley, D.C., Beach, R.A., 2003. Cross-shore sediment partitioning in the nearshore during a storm event. Journal of Geophysical Research 108 (C3), 1-13.

Dadisman, S.V., Hill, J.C., Schwab, W.C., 2001a. Archive of Datasonics SIS-1000 chirp sub-bottom data collected during USGS cruise MGNM00014, central South Carolina, 13-30 March 2000. U.S. Geological Survey Open-File Report, 00-462, 4 CD-ROMs.

Dadisman, S.V., Hill, J.C., Schwab, W.C., 2001b. Archive of boomer sub-bottom data collected during USGS MGNM00014, central South Carolina, 13-30 March 2000. U.S. Geological Survey Open-File Report, 00-462, 4 CD-ROMs.

Demarest, J.M., Leatherman, S.P., 1985. Mainland influence on coastal transgression: Delmarva Peninsula. Marine Geology 63, 19-33.

Denison, P., 1998. Beach renourishment/groin field construction project: Bald Head Island. N.C.: Shore and Beach, 2-9, Jan 1998.

Denny, J.F., Baldwin, W.E., Schwab, W.C., Gayes, P.T., Morton, R.A., Driscoll, N.W., 2007. Morphology and texture of modern sediments on the inner shelf of South Carolina's Long Bay from Little River Inlet to Winyah Bay. U.S. Geological Survey Open-File Report, 2005-1345, 〈http://pubs.usgs.gov/of/2005/1345// 〉.

Douglas, S.L., 1995. Estimating landward migration of nearshore constructed sand mounds. J. Waterw. Port. Coastal and Ocean Engineering 121 (5), 247-250.

DuBar, J.R., 1971. Neogene stratigraphy of the lower coastal plain of the Carolinas: Atlantic Coastal Plain Geological Association, In: Proceedings of the 12th Annual Field Conference, Myrtle Beach, S.C., 1971 [Guidebook], 128 p.

DuBar, J.R., DuBar, S.S., 1980. Neogene biostratigraphy and morphology of northeastern South Carolina, In: Frey, R.W., (Ed.), Excursions in southeastern geology: Georgia: Falls Church, Virginia, Geological Society of America 1980 Annual Meeting Guidebook, Field Trip No. 9, Atlanta, pp. 179-189.

DuBar, J.R., Johnson Jr., H.S., Thom, B., Hatchell, W.O., 1974. Neogene stratigraphy and morphology, south flank of the Cape Fear Arch, North and South Carolina. In: Oaks, R.Q., DuBar, J.F. (Eds.), Post-Miocene stratigraphy, central and southern Atlantic Coastal Plain. Utah State University Press, Logan, pp. 139-173.

Evans, M.W., Hine, A.C., Belknap, D.F., Davis Jr., R.A., 1985. Bedrock controls on barrier island development: West-central Florida coast. Marine Geology 63, 263-283.

Finkl, C.W., Pilkey, O.H., 1991. Impacts of Hurricane Hugo: September 10-22, 1989. Journal of Coastal Research, Special Issue No. 8, i-iv.

Gardner, L.R., Porter, D.E., 2001. Stratigraphy and geologic history of a southeastern salt marsh basin, North Inlet, South Carolina, USA. Wetlands Ecology and Management 9, 371-385.

Gayes, P.T., 1991. Post Hurricane Hugo nearshore sidescan-sonar survey; Myrtle Beach to Folly Beach, South Carolina, In: Finkl, C.W., Pilkey, O.H. (Eds.), Journal of Coastal Research, Special Issue 8, pp. 95-111.

Gayes, P.T., Baldwin, W.E., Van Dolah, R.F., Jutte, P., Eiser, W.C., Hansen, M., 2001 Systematic Coastal Monitoring: The South Carolina Coast (USA). In: Kraus, N., Hansen, H. (Eds.), Coastal Dynamics. ASCE, Lund, Sweden.

Gayes, P.T., Nelson, D.D., Ward, T., 1992. Ancestral channels of the ancient Pee Dee River on the inner continental shelf off Murrells Inlet, South Carolina. Southeastern Geology 34 (1 \& 2), 53-56.

Gayes, P.T., Schwab, W.C., Driscoll, N.W., Morton, R.A., Baldwin, W.E., Denny, J.F. Harris, M.S., Wright, E.E., Katuna, M.P., 2003. Sediment dispersal pathways and conceptual sediment budget in Long Bay: a southeast U.S. sediment starved embayment. In: Proceedings of the Coastal Sediments. '03, Clear Water Beach, Florida, 18-23, pp. 1-14. 
Giles, R.T., Pilkey, O.H., 1965. Atlantic beach and dune sediments of the southern United States. Journal of Sedimentary Petrology 35, 900-910.

Goff, J.A., Swift, D.J.P., Duncan, C.S., Mayer, L.A., Hughes-Clarke, J., 1999. High resolution swath sonar investigation of sand ridge, dune and ribbon morphology in the offshore environment of the New Jersey margin. Marine Geology 161, 309-339.

Hallermeier, R.J., 1981a. A profile zonation for seasonal sand beaches from wave climate. Coastal Engineering 4, 253-277.

Hallermeier, R.J., 1981b. Seaward limit of significant sand transport by waves: An annual zonation for seasonal profiles. Forth Belvoir, Virginia: U.S. Army Corps of Engineers, CERC, Coastal Engineering Technical Aid No. 81-7, 119.

Harris, M.S., Gayes, P.T., Kindinger, J.L., Flocks, J.G., Krantz, D.W., Donovan, P., 2005 Quaternary geomorphology and modern coastal development in response to and inherent geologic framework: An Example from Charleston, South Carolina. Journal of Coastal Research 21, 49-64.

Hayes, M.O., 1994. The Georgia Bight barrier system. In: Davis Jr., R.A. (Ed.), Geology of Holocene Barrier Island Systems. Springer-Verlag, New York, pp. 233-304.

Hayes, M.O., Michel, J., 2008. A Coast for all seasons: a naturalist's guide to the coast of South Carolina. Pandion Books, Columbia, South Carolina.

Hayes, M.O., Nairn, R.B., 2004. Natural Maintenance of sand ridges and linear shoals on the U.S. Gulf and Atlantic continental shelves and the potential impacts of dredging. Journal of Coastal Research 20 (1), 138-148.

Hayes, M.O., Sexton, W.J., Colquhoun, D.J., Eckard, T.L., 1993. Evolution of the Santee/Pee Dee delta complex, South Carolina, USA. In: Kay, R. (Ed.), Deltas of the World. American Society of Civil Engineers, New York, N.Y., USA, pp. 54-64.

Heilman, D.J., Darnell, J.T., Mahoney, M.P., 2006. The closure depth paradox: implications for sediment budget at Padre Island, Texas. In: Proceedings of the 30th International Coastal Engineering Conference, (San Diego, California ASCE), pp. 3391-3403.

Hill, J.C., Schwab, W.C., Dadisman, S., Danforth, W.W., Denny, J.F., O'Brien, T.F., Parolski, K., 2000a. Archive of chirp data collected during USGS cruise ATSV99044 Myrtle Beach, South Carolina, 29 October-14 November 1999. U.S. Geological Survey Open-File Report, 00-040, 9 CD-ROMs.

Hill, J.C., Schwab, W.C., Dadisman, S.V., Danforth, W.W., Denny, J.F., O'Brien, T.F., Parolski, K.F., 2000b. Archive of boomer sub-bottom data collected during USGS cruise ATSV99044 Myrtle Beach, South Carolina, 29 October-12 November 1999. U.S. Geological Survey Open-File Report, 00-153, 18 CD-ROMs.

Hine, A.C., Snyder, S.W., 1985. Coastal lithosome preservation: evidence from the shoreface and inner continental shelf off Bogue Banks, North Carolina. Marine Geology 63, 307-330.

Hinton, J.M., Nicholls, R.J., 2007. Shoreface morphodynamics along the Holland coast. In: Balson, P.S., Collins, M.B. (Eds.), Coastal and Shelf Sediment Transport, 274. Geological Society of London Special Publications, London, pp. 91-101.

Hubbard, D.K., Oertel, G., Nummedal, D., 1979. The role of waves and tidal currents in the development of tidal-inlet sedimentary structures and sand body geometry: Examples from North Carolina, South Carolina, and Georgia. Journal of Sedimentary Petrology 49, 1073-1092.

Kana, T.W., 1995. A mesoscale sediment budget for Long Island, New York. Marine Geology 126, 87-110.

Lee, G., Birkemeier, W.A., 1993. Beach and nearshore survey data: 1985-1991 CERC Field Research Facility. Vicksburg, Mississippi: U.S. Army Corps of Engineers, CERC, Technical Report CERC-93-3.

Lennon, G., Neal, W.J., Bush, D.M., Pilkey Jr., O.H., Stutz, M., Bullock, J., 1996. Living with the Coast of South Carolina. Duke University Press, Durham, NC, pp. 241.

Locker, S.D., Hine, A.C., Brooks, G.R., 2003. Regional stratigraphic framework linking continental shelf and coastal sedimentary deposition of west-central Florida. Marine Geology 200, 351-378.

McCartan, L., Lemon Jr., E.M., Weems, R.E., 1984. Geologic map of the area between Charleston and Orangeburg. South Carolina: U.S. Geological Survey Map I-1472, scale 1250,000

McBride, R.A., Moslow, T.F., 1991. Origin, evolution, and distribution of shoreface sand ridges, Atlantic inner shelf, USA. Marine Geology 97, 57-85.

Milliman, J.D., Pilkey, O.H., Ross, D.A., 1972. Sediments of the Continental Margin off the Eastern United States. Geological Society of America Bulletin 83, 1315-1334.

Miselis, J.L., McNinch, J.E., 2006. Calculating shoreline erosion potential using nearshore stratigraphy and sediment volume: Outer Banks, North Carolina. Journal of Geophysical Research 111, 1-15.

Morton, R.A., Miller, T.L., 2005. National assessment of shoreline change: Part 2 Historical shoreline changes and associated coastal land loss along the U.S southeast Atlantic coast. U.S. Geological Survey Open-File Report 2005-1401 $\langle$ http://pubs.usgs.gov/of/2005/1401 〉.

Morton, R.A., Gibeaut, J.C., Paine, J.G., 1995. Meso-scale transfer of sand during and after storms: implications for prediction of shoreline movement. Marine Geology 126, 161-179.

National Oceanographic and Atmospheric Administration (NOAA)-National Geophysical Data Center (NGDC), 2001. Coastal relief model-U.S. Southeast Atlantic coast, Boulder, Colorado: NOAA-NGDC, v. 2, CD-ROM.

Nelson, D.D., 1991. Factors effecting beach morphology changes caused by Hurricane Hugo, Northern South Carolina. Journal of Coastal Research, Special Issue No. 8, pp. 163-179.

Nicholls, R.J., Birkemeier, W.A., Lee, G.H., 1998. Evaluation of depth of closure using data from Duck, N.C., USA. Marine Geology 148, 179-201.
Nittrouer, C.A., Wright, L.D., 1994. Transport of particles across continental shelves. Reviews of Geophysics 32, 85-113.

Ojeda, G.Y., Gayes, P.T., Van Dolah, R.F., Schwab, W.C., 2004. Spatially quantitative seafloor habitat mapping; example from the northern South Carolina inner continental shelf. Estuarine, Coastal and Shelf Science 59, 399-416.

Owens, J.P., 1989. Geologic map of the Cape Fear region, Florence $1^{\circ} \times 2^{\circ}$ quadrangle and northern half of the Georgetown $1^{\circ} \times 2^{\circ}$ quadrangle, North Carolina and South Carolina: U.S. Geological Survey, Miscellaneous Investigations Series Map I-1948-A, scale 1:250,000.

Park, J., Gayes, P.T., Wells, J.T., 2009. Monitoring Beach renourishment along the sediment-starved shoreline of Grand Strand, South Carolina. Journal of Coastal Research 25 (2), 336-349.

Patchineelam, S.M., Kjerfve, B., Gardner, L.R., 1999. A preliminary sediment budget for the Winyah Bay estuary, South Carolina, USA. Marine Geology 162, 133-144.

Pierce, J.W., 1969. Sediment Budget along a barrier island chain. Sedimentary Geology 3, 5-16.

Pilkey, O.H., Blackwelder, B.W., Knebel, H.J., Ayers, M.W., 1981. The Georgia Embayment continental shelf; Stratigraphy of a submergence. Geologic Society of America Bulletin 92, 52-63.

Pilkey, O.H., Field, M.E., 1972. Onshore transportation of continental shelf sediment In: Swift, D.J.P., Duane, D.B., Pilkey, O.H. (Eds.), Shelf Sediment Transport: Process and Pattern. Duane, Hutchinson and Ross, Inc, Pennsylvania, pp. 429-446.

Pilkey, O.H., Young, R.S., Riggs, S.R., Smith, A.W., Wu, H., Pilkey, W.D., 1993. The concept of shoreface profile of equilibrium: a critical review. Journal of Coastal Research 9, 255-278.

Poppe, L.J., Eliason, A.H., Fredricks, J.J., 1985. APASA—An Automated Particle Size Analysis System. U.S. Geological Survey Circular 963, 1-7.

Putney, T.R., Katuna, M.P., Harris, M.S., 2004. Subsurface stratigraphy and geomorphology of the Grand Strand, Georgetown and Horry Counties, South Carolina. Southeastern Geology 42 (4), 217-236.

Riggs, S.R., Ambrose, W.G., Cook, J.W., Snyder, S.W., 1998. Sediment production on sediment-starved continental margins; the interrelationship between hardbottoms, sedimentological and benthic community processes, and storm dynamics. Journal of Sedimentary Research 68 (1), 155-168.

Riggs, S.R., Cleary, W.J., Snyder, S.W., 1995. Influence of inherited geologic framework on barrier shoreface morphology and dynamics. Marine Geology 126, 213-243.

Riggs, S.R., Snyder, S.W., Hine, A.C., Mearns, D.L., 1996. Hardbottom Morphology and relationship to the geologic framework; Mid-Atlantic continental shelf. Journal of Sedimentary Research 66 (4), 830-846.

Roberts, C., Hammar-Klose, E., Schwab, W.C., 2002. Archive of sidescan-sonar data and DGPS navigation data collected during USGS cruise ATSV99044, South Carolina coast, 29 October-14 November. U.S. Geological Survey Open-File Report, 02-103, 5 CD-ROMs.

Schwab, W.C., Allison, M.A., Corso, W., Lotto, L.L., Butman, B., Buchholtz ten Brink M., Denny, J.F., Danforth, W.W., Foster, D.S., 1997. Initial Results of highresolution sea-floor mapping offshore of the New York-New Jersey metropolitan area using sidescan sonar. Northeastern Geology and Environmental Sciences 19 (4), 243-262.

Schwab, W.C., Thieler, E.R., Allen, J.R., Foster, D.S., Swift, B.A., Denny, J.F., 2000. Influence of inner-continental shelf geologic framework on the evolution and behavior of the barrier-island system between Fire Island Inlet and Shinnecock Inlet, Long Island, New York. Journal of Coastal Research 16 (2), 408-422.

Schwab, W.C., Baldwin, W.E., Hapke, C.J., Lentz, E.E., Gayes, P.T., Denny, J.F., List, J.H., Warner, J.C., 2013. Geologic evidence for onshore sediment transport from the inner continental shelf: Fire Island, New York, Journal of Coastal Research, http://dx.doi.org/10.2112/JCOASTRES-D-12-00160.

Slovinsky, P.A., 2001. Spatial Variation of beach morphology along coastal South Carolina, unpublished Masters Thesis, University of South Carolina.

Snedden, J.W., Kreisa, R.P., Tillman, R.K., Culver, S.J., Schweller, W.J., 1999. An expanded model for modern shelf sand ridge genesis and evolution on the New Jersey Atlantic shelf, In: Bergman, K.M., Snedden, J.W. (Eds.), Isolated Shallow Marine Sand Bodies: Sequence Stratigraphic Analysis and Sedimentologic Interpretation. Tulsa, Oklahoma: SEPM (Society for Sedimentary Geologist) Special Publication No. 64, pp. 147-164.

Snedden, J.W., Nummedal, D., Amos, A.F., 1988. Storm- and fair-weather combined flow on the central Texas continental shelf. Journal of Sedimentary Petrology $58,580-595$.

Stauble, D.K., Seabergh, W.C., Hales, L.Z., 1991. Effects of Hurricane Hugo on the South Carolina Coast. Journal of Coastal Research, Special Issue No. 8, pp. 129-162.

Thieler, E.R., Brill, A.L., Cleary, W.J., Hobbs, C.H., Gammisch, R.A., 1995. Geology of the Wrightsville Beach, North Carolina shoreface; Implications for the concept of shoreface profile of equilibrium. Marine Geology 126, 271-287.

Thieler, E.R., Pilkey, O.H., Cleary, W.J., Schwab, W.C., 2001. Modern sedimentation on the shoreface and inner continental shelf at Wrightsville Beach, North Carolina, U.S.A. Journal of Sedimentary Research 71 (6), 958-970.

Trowbridge, J.H., 1995. A mechanism for the formation and maintenance of the shore oblique sand ridges on storm-dominated shelves. Journal of Geophysical Research 100 (C8), 16,071-16,086.

USACE (U.S. Army Corps of Engineers), 2007. Environmental Assessment for the Grand Strand storm damage reduction project North Myrtle Beach, Myrtle Beach \& Surfside Beach, South Carolina, Horry \& Georgetown Counties, Draft Formulation Report, Charleston District, USACE, South Carolina, 216.

Van de Meene, J., Van Rijn, L., 2000. The shoreface-connected ridges along the central Dutch coast-part 1: field observations. Continental Shelf Research 20, 2295-2323. 
Vis-Star, N.C., de Swart, H.E., Calvete, D., 2007. Effect of save-topography interactions on the formation of sand ridges on the shelf. Journal of Geophysical Research 112 (C6), 1-17.

Warner, J.C., Armstrong, B., Sylvester, C.S., Voulgaris, G., Nelson, T., Schwab, W.C., Denny, J.F., 2012. Storm-induced inner-continental shelf circulation and sediment transport: Long Bay, South Carolina. Continental Shelf Research 42, 51-63.

Wehmiller, J.F., York, L.L., Bart, M.L., 1995. Amino acid racemization geochronology of reworked Quaternary mollusks on U.S. Atlantic Coast beaches: implications for chronostratigraphy, taphonomy, and coastal sediment transport. Marine Geology 124, 303-337.

Wright, E., Gayes, P.T., Donovan-Ealy, P., Baldwin, W., Harris, M.S., 1999. Assessment of beach nourishment resources on the inner shelf, seaward of Pawleys
Island, South Carolina: Final Report of the South Carolina Task Force on Offshore Resources to the Minerals Management Service Office of International Activities and Mineral Resources, p. 17.

Wright, L.D., 1987. Shelf-surfzone coupling: diabathic shoreface transport In: Proceedings of the Coastal Sediments '87. New York, New York, ASCE, pp. 25-40.

Wright, L.D., Boon, J.D., Kim, S.C., List, J.H., 1991. Modes of cross-shore sediment transport on the shoreface of the Middle Atlantic Bight. Marine Geology 96, 19-51.

Xu, J.P., Wright, L.D., 1998. Observations of wind-generated currents off Duck, North Carolina. Journal of Coastal Research 14, 610-619. 